\author{
Michał ZABDYR-JAMRÓZ \\ Uniwersytet Jagielloński \\ E-mail: michal.zabdyr.jamroz@gmail.com
}

\title{
ZASADA RZĄDÓW PRAWA W KONCEPCJI ALBERTA VENN DICEYA
}

\section{ABSTRACT The principle of the rule of law in Albert Venn Dicey's theory}

The aim of this paper is to present the original theory of the English rule of law developed by Victorian-era constitutional scholar, Albert Venn Dicey. The uniqueness of this theory will be presented, as well as its historical and doctrinal context, and theoretical implications. Dicey's legal positivism identifies the rule of law as one of the two basic principles of the English unwritten constitution (together with the principle of sovereignty of Parliament). The rule of law itself consists of three components - the ideas of legal freedom, legal equality and predominance of the legal spirit. The latter is due to the inductive nature of the British constitution and in practice results in a strong emphasis on the institutional guarantees of the rule of law. The second idea - legal equality - in Dicey's opinion interfered with the concept of administrative law, as it was developed on the European continent thus making it manifestly contrary to the English rule of law.

KEY WORDS Albert Venn Dicey, rule of law, English constitutionalism, administrative law

Teraz odchodzisz pokrzywdzony, jeśli odejdziesz, ale krzywda cie nie od nas, nie od praw spotyka, tylko od $l u d z i$.

Platon, Kriton ${ }^{1}$

Platon, Kriton, [w:] tenże, Obrona Sokratesa. Kriton. Uczta, przeł. W. Witwicki, Warszawa 2008, s. 91, Biblioteka Filozofów, 1. 


\section{WSTĘP}

Albert Venn Dicey - brytyjski dziennikarz, polityk i przede wszystkim prawnik-konstytucjonalista ery wiktoriańskiej, profesor common law na Uniwersytecie Oxfordzkim oraz w London School of Economics. Żył w latach 1835-1922. Wywodził się z postępowych środowisk liberałów benthamowskich i ewangelików (jego rodzicami byli wigowski działacz społeczny Thomas Edward Dicey oraz Anne Mary Stephen). Osobiście poczuwat się do etosu reformatorskiego - jako zwolennik indywidualizmu i laisser-fair wyrażał poparcie dla obywatelskiego nieposłuszeństwa względem niesprawiedliwego prawa. Jednak ewolucja jego poglądów usytuowała go ostatecznie na pozycjach konserwatywnego wigizmu. Przejawiło się to m.in. w kontekście sporu o nadanie samorządności Irlandii (tzw. Home Rule), w którym opowiedział się zdecydowanie przeciw dewolucji Zjednoczonego Królestwa razem z tzw. liberalnymi unionistami. Mimo początkowego poparcia emancypacji kobiet, w kwestii nadania im praw wyborczych przyjął pozycję wyraźnego sceptycyzmu, podobnie zresztą jak względem idei powszechności prawa wyborczego ${ }^{2}$.

Dicey jako jeden z pierwszych popierał za to - mimo uznawania prymatu zasady suwerenności parlamentu - stosowanie referendum jako formy partycypacji obywateli $\mathrm{w}$ procesie ustawodawczym (w roli weta ludowego). W instrumencie tym dostrzegat użyteczne narzędzie korekty wad funkcjonowania systemu partyjnego ${ }^{3}$. Jego rozważania odcisnęły wyraźne piętno na nauce brytyjskiego konstytucjonalizmu, do którego wprowadził dojrzały namysł w duchu pozytywizmu prawnego. Rozpropagował koncepcję suwerenności parlamentu i supremacji stanowionego przezeń prawa powszechnego (tzw. rządów prawa), jako dwóch kierowniczych zasad catej konstytucji angielskiej. Starał się godzić bliski swoim poglądom benthamowski pozytywizm prawny, który absolutyzował rolę legislatywy, z tradycją opartego na silnej roli precedensów common law, którą sam Bentham bezwzględnie krytykował ${ }^{4}$. Dla Diceya zwornikiem łączącym common law i benthamizm była wspólna dla nich zasada indywidualizmus.

2 A.V. Dicey, Letters to a Friend on Votes for Women, London 1909, s. 55-76, [online] http://www.keele. ac.uk/history/currentundergraduates/tltp/SUFFRAGE/DOCUMENT/DICEYLEA.HTM\#Ret3, 20 VI 2010.

3 M. Qvortrup, A.V. Dicey. The Referendum as the People's Veto, „History of Political Thought” 1999, Vol. 20, nr 3, s. 531-546; zob. także: V. Bogdanor, The New British Constitution, Oxford-Portland 2009, s. 186. Zdaniem niektórych to stanowisko Diceya było rażąco sprzeczne z jego doktryną i miało wynikać przede wszystkim z jego politycznego zaangażowania po stronie liberalnych unionistów, jako że referendum w tym przypadku miało zablokować próby dewolucji ustroju terytorialnego Zjednoczonego Królestwa (zob.: R.A. Cosgrove, The Rule of Law. Albert Venn Dicey, Victorian Jurist, London 1980, s. 105-110, 247). Zdaniem innych była to logiczna konsekwencja odróżnienia przez Diceya suwerenności legalnej (którą przypisał Parlamentowi) od suwerenności politycznej (przynależnej Ludowi) (zob.: R. Weill, Dicey Was Not Diceyan, „The Cambridge Law Journal” 2003, Vol. 62, nr 2, s. 474).

4 Zob.: J. Bentham, Fragment on Government, [w:] tenże, The Works of Jeremy Bentham, t. 1 [na podstawie zbioru pod red. J. Browninga, Edinburgh 1843], s. 442-537, [online] http://oll.libertyfund. org/title/2009, 29 XI 2012.

5 Benthamism was, and was ultimately felt to be, little else than the logical and systematic development of those individual rights, and especially of that individual freedom which has always been dear to the 
Pośród naczelnych prac Diceya wymienia się następujące: Essays on Reform (1867), An Introduction to the Study of the Law of the Constitution (1885), A Digest of the Law of England with Reference to the Conflict of Laws (1896), The Privy Council (1887) oraz Lectures on the Relation Between Law \& Public Opinion in England (1905). An Introduction... ${ }^{6}$ - czyli Wprowadzenie do nauki o prawie konstytucji z 1885 r. - najpelniej prezentowała poglądy Diceya na temat niepisanej konstytucji brytyjskiej i idei rule of law w ogóle. Uznawana po dziś za naczelną, obok Law \& Public Opinion ${ }^{7}$, a będąca swego czasu powodem burzliwej debaty, odcisnęła wielkie piętno na nauce brytyjskiego konstytucjonalizmu i na obraz tegoż na kontynencie. Polskiego wydania doczekała się w r. 1908, na podstawie szóstej edycji anglojęzycznej z 1902 r. Zaopatrzono je w rozbudowany Dodatek autora ${ }^{8}$.

Artykuł ten ma na celu prezentację oryginalnej koncepcji tego autora na temat zagadnienia rządów prawa, wraz z jej kontekstem w systemie teoretycznym Diceya (szczególnie w zestawieniu z ideą zwierzchnictwa parlamentu) $)^{9}$, a także aspektami poszczególnymi (problemem wolności), uwarunkowaniami (doktryny zawarte implicite w poszczególnych aktach prawnych i explicite w pismach filozofów i prawników) oraz znamiennymi konsekwencjami teoretycznymi (odniesienie do koncepcji prawa administracyjnego). Jakkolwiek owe zganienia poboczne nie są same w sobie przedmiotem opracowania Diceya, to zgodnie z jego własnymi uwagami stanowią punkty newralgiczne jego koncepcji rządów prawa, stąd tak wiele miejsca będzie im poświecone. Używając słów samego autora Wstępu... (zachowując urok polskiego przekładu z 1908 r.): choć przedmiotem pracy tej nie jest - o czem czytelnik pamiętać winien - studyum szczegótowe i doktadne aktów Habeas Corpus np. lub innych praw ${ }^{10}$, to nieodzowny okaże się bliższy wgląd w te zagadnienia z dziejów angielskiego prawa (szczególnie w burzliwym XVII w.). Jak można się bowiem dowiedzieć, biorąc Maitlanda na świadka, historia tego writu [habeas corpus] jest do prawdy historia naszej [angielskiej] konstytucji ${ }^{11}$.

common law of England (A.V. Dicey, Lectures on the Relation between Law and Public Opinion during the 19th Century, [London 1919], s. 115, [online] http://oll.libertyfund.org/title/1683, 29 XI 2012.

6 Tenże, An Introduction to the Study of the Law of the Constitution, wstęp i dodatek E.C.S. Wade, London 1945. Cytowane fragmenty pochodzić będą właśnie z tego wydania: z zachowaniem oryginalnej ortografii, interpunkcji i fleksji.

7 Tenże, Lectures on the Relation between Law and Public Opinion in England, Indianapolis 2008 [na podstawie wydania z roku 1917].

8 Tenże, Wstęp do nauki o prawie konstytucyjnem, przeł. W.H., Warszawa 1908, s. 117-132.

9 Diceya wizja suwerennego Parlamentu jako ucieleśnienia mechanizmu przekładania powszechnej opinii publicznej na prawo - w której to nie istnieje sprzeczność między absolutyzmem Parlamentu a podstawowymi prawami jednostki - nie będzie tutaj zgłębiana, gdyż zasługuje na omówienie osobne.

10 Tamże, s. 140.

11 F.W. Maitland, The Constitutional History of England, Cambridge 1908, s. 539. Maitland pisze dalej: gdyby król byt w stanie posytać do w więzienia bez podawania jakiejkolwiek przyczyny, miatby w swoich rękach potężne narzędzie do kontrolowania Parlamentu i mogty powieść się jego starania zmierzające do uczynienia go monarcha absolutnym (tamże). Przekład własny $\mathrm{z}$ : the history of the writ is very truly part of the history of our constitution; if the king had been able to commit to prison without giving any reason, 
Podobnie jest z ideą prawa administracyjnego, do której odniesienie wyjaśni charakter rzeczywisty rządów, jakie widzimy w Anglii ${ }^{12}$.

\section{UWAGI WPROWADZAJĄCE. RZĄDY PRAWA I PAŃSTWO PRAWA W LITERATURZE PRZEDMIOTU}

Dicey o angielskich rządach prawa (rule of law) pisał w przekonaniu, że wciąż jeszcze w jego czasach są unikalną cecha charakterystyczna Anglii, jej instytucji, a nawet wyjątkowym rysem charakteru narodowego (do tego stopnia, że zestawia on ustrój brytyjski z historycznie na wpół despotycznymi państwami kontynentu $)^{13}$. Takie twierdzenie jednak będzie oczywiście zasadne tyko pod warunkiem, że uznamy rule of law za specyficznie angielskie wcielenie szerszej idei praworządności.

Idea ta rozwijana była co najmniej od antyku ${ }^{14}$. Już w czasach Diceya miała swoje rozwinięte odmiany także po drugiej stronie Kanału, gdzie występowała pod imieniem państwa prawa czy też państwa prawnego - w Niemczech: der Rechtsstaat ${ }^{15}$, a we Francji: l'état de droit. Tak jak Dicey odpowiada za popularyzację terminu rule of law w świecie anglosaskim, tak Robert von Mohl rozpropagował Rechtsstaat w swojej Nauce policji zgodnie z zasadami państwa prawnego z $1832 \mathrm{r} .{ }^{16}$ Zastrzec należy w tym miejscu, że w nauce o praworządności / państwie prawa można wyróżnić (głównie przez wzgląd na praktykę ustrojową i doktrynę konstytucjonalizmu) co najmniej trzy jej historyczne tradycje - narodowe odmiany: angielską, niemiecką i francuską ${ }^{17}$. W tym miejscu jednak skoncentrujemy się na przywołaniu najogólniejszych tylko informacji, które stanowić będą punkt odniesienia dla zrozumienia specyfiki koncepcji Diceya ${ }^{18}$.

he would have had at his command a potent engine for controling parliament, and might have succeeded in his effort to make himself an absolute monarch.

12 A.V. Dicey, Wstęp..., s. 132.

13 Tamże, s. 117-132 (119); tenże, Introduction..., s. 183-205.

14 Zob.: Arystoteles, Polityka, przel. L. Piotrowicz, Warszawa 2006, s. 115.

15 Zob.: R. von Mohl, Encyklopedia umiejętności politycznych, t. 1, przeł. A. Białecki, A. Bosiacki, Warszawa 2003, s. 278-314 [pierwsze wydanie: 1859].

16 Tenże, Die Polizeiwissenschaft nach den Grundlagen des Rechtsstaates, t. 1, Tübingen 1832, za: A. Bosiacki, Wstęp, [w:] R. von Mohl, Encyklopedia..., s. XIII.

17 A.J.É. Fouillée, Lidée moderne du droit en Allmagne, en Angleterre et en France, Paris 1878, za: B. Jasinowski, Wschodnie chrześcijaństwo a Rosja, wstęp M. Kornat, Kraków 2002, s. 140 i nast., Biblioteka Klasyki Polskiej Myśli Politycznej, t. 9.

18 Poniższe uwagi opracowane zostały na podstawie następujących źródeł: Leksykon politologii, red. A. Antoszewski, R. Herbut, Wrocław 2002, s. 341-342; S. Kaźmierczyk, Jak rozumieć państwo prawne, [w:] Teoria i filozofia prawa. Wybór tekstów, red. W. Gromski, Wrocław 1998, s. 78-86, Podręczniki Wydziatu Prawa i Administracji Uniwersytetu Wroctawskiego; J.M. Kelly, Historia zachodniej teorii prawa, przeł. D. Pietrzyk-Reeves [i in.], Kraków 2006, s. 311-316; L. Morawski, Wstęp do prawoznawstwa, Toruń 2002, s. 237-247; L. Petrażycki, O nauce, prawie i moralności. Pisma wybrane, wybór J. Licki, A. Kojder, oprac. A. Kojder, Warszawa 1985, s. 330, Biblioteka Socjologiczna; G. Radbruch, Państwo praworzadne, [w:] tenże, Filozofia prawa, przeł. E. Nowak, Warszawa 2009, s. 193-199; R. Scruton, 
Polityczny ideat praworządności zasadza się na postulacie, że rządzić ma prawo, a nie ludzie. Chodzi o sprawienie, by - inaczej niż w rządach spersonalizowanych - władza wspólnoty politycznej nie była determinowana przez kaprys partykularnej woli lub osobiste interesy panujących. $Z$ tej perspektywy ustrój oparty na tej zasadzie - nomokracja - przeciwstawić można nadużyciom właściwym innym formom ustrojowym (rozumianym jako coś więcej niż tylko system rządów): tyranii większości - w demokracji; tyranii możnych - w oligarchii; tyranii jednostki - w monarchii. Początków kształtowania się współczesnej wizji praworządności - szczególnie zaś popularyzacji jej idei w duchu równości wobec prawa - upatruje się dobie oświecenia, u filozofów takich jak John Locke czy Monteskiusz oraz autorytetów prawnych w typie Williama Blackstone’a. Punktem odniesienia dla niej był właśnie postulat, że rządzący - szczególnie monarchowie - nie stoją ponad prawem.

$\mathrm{Z}$ teoretycznej perspektywy idea rządów prawa polega na aplikowaniu we wszystkich przypadkach szczególnych (indywidualno-konkretnych) ogólnych (generalno-abstrakcyjnych) norm lub reguł prawa. W tym sensie prawa - inaczej niż ludzie - rządzą w sposób niestronniczy, zobiektywizowany i neutralny i czynią ludzi równymi. I tak, pierwotnie po raz pierwszy idea ta zaistniała w pełni wraz z realizacją zasady $i z$ on om $i i$ - równości wobec prawa i $w$ prawach. W tym z kolei sensie rządy prawa kojarzy się nierozerwalnie z ustrojem demokratycznym w jego klasycznym rozumieniu, ujętym w mowie Peryklesa ${ }^{19}$. Współcześnie dodaje się do niej dodatkowo zasadę ustrojową praw jednostki i konstytucjonalizmu. Gdy zaś idzie o praktykę, w literaturze przedmiotu akcentuje się kluczową rolę kultury politycznej i prawnej społeczeństwa - z wyraźnym wskazaniem na postawy elit politycznych.

Praworządność - lub też rządy prawa (okazjonalnie także państwo prawa) - to zasada urządzenia stosunków społecznych, zgodnie z którą instytucje władzy publicznej, w szczególności państwa, jak również jego obywatele, postępują w zgodzie z prawem. Ze względu na zakres podmiotowy definicja ta jest ro z u m i e n i e m s zers zy m. Gdy ogranicza się rzeczony wymóg do instytucji władzy publicznej, mamy do czynienia z praworządnością sensu stricto. W ostatnim przypadku szczególnie wyraźnie ucieleśnia się postulat, by rzadzito prawo, a nie ludzie - generalno-abstrakcyjne reguły, a nie arbitralny kaprys urzędnika czy władcy. W tym kontekście rodzi się dylemat zakresu swobody decyzyjnej funkcjonariuszy władzy publicznej: zbyt duża dyskrecjonalność urzędnicza może generować arbitralność i korupcję; zbyt wąski zakres uprawnień może być okupiony brakiem elastyczności i efektywności. Z tej bowiem perspektywy ujawnia się nie tylko negatywny aspekt praworządności - prawo nie może być naruszane ale i jej wymiar pozytywny - prawo powinno być (sprawnie) wykonywane.

Pojęcie praworządności może być brane w z na czen niu normatywnym, kiedy to stanowi postulat (zabezpieczenia przed arbitralnością władców) i jako wartość po-

Stownik myśli politycznej, przeł. T. Bieroń, Poznań 2002, s. 358; B. Szlachta, Prawo, [w:] Stownik spoteczny, red. B. Szlachta, Kraków 2004; W. Zamkowski, Koncepcje i modele państwa prawnego, [w:] Teoria ifilozofia prawa..., s. 88-99.

19 Zob.: Tukidydes, Wojna peloponeska, przeł. K. Kumaniecki, Warszawa 1988, s. 107. 
lityczna jest podstawowym składnikiem normatywnej teorii demokracji; jak i e m pi r y c z n y m, gdy opisuje stan faktycznej realizacji rzeczonego postulatu, a w takim rozumieniu z konieczności stanowi pewną idealizację.

Ze względu na aspekt genetyczny i funkcjonalny wyróżnia się p raw o r ząd n ość formalną (A) i materialną (B).

W przypadku tej pierwszej (A), określonej przez Friedricha Hayeka jako praworządność zwyczajna, wymaga się wyłącznie przestrzegania prawa obowiązującego na danym terytorium, jakiekolwiek ono by nie było w swej treści ( $\mathrm{w}$ myśl zasady dura lex sed lex), pod warunkiem wszakże - i jest to warunek podstawowy - że (A1) spełnia ono określone kryteria formalne, a są to: (A1.a) hierarchiczność systemu źródeł (z konstytucją na szczycie); (A1.b) obowiązek promulgacji i (A1.c) jednoznaczności; (A1.d) prospektywność; (A1.e) spójność oraz (A1.f) zupełność. Praworządność formalna zakłada, że organy władzy (A2) nie mogą działać poza prawem, wedle swojego kaprysu - mogą czynić tylko to, na co prawo wyraźnie im pozwala (wiąże się to z negatywnym aspektem nadrzędności konstytucji); (A3) mogą jedynie stosować prawo, rozwijając ogólne akty prawne i konkretyzując przepisy konstytucyjne (pozytywny aspekt nadrzędności konstytucji). Obywatelowi, wedle konstytucji, wolno wszystko to, czego prawo nie zakazuje, a więc wolność indywidualną można ograniczyć tylko na podstawie prawa (ustawy) - tylko prawo może wyznaczać zakres podległości obywatela organom publicznym. Ponadto wymogiem praworządności formalnej jest, by (A4) organy władzy działały wyłącznie zgodnie z określonymi prawem procedurami (sprawiedliwość proceduralna), a także (A5) by istniały odpowiednie instytucje i procedury - zwane gwarancjami - umożliwiające kontrolę konstytucyjności ustaw i legalności aktów administracyjnych (instytucja skargi, trybunały lub sądy konstytucyjne, sądowa kontrola administracji, rzecznicy praw itd.). Powyższe wiąże się również z ustanowieniem jasnych reguł egzekwowania odpowiedzialności politycznej i prawnej przez poszkodowanych obywateli.

(B) Praworządność materialna tymczasem jest już doktryną metaprawną, ponieważ poszerza wymogi praworządności formalnej o konieczność spełniania przez prawo, poza wyżej wymienionymi wymogami formalnymi, także wymogów materialnych, a konkretnie jego zgodności z katalogiem wartości nadrzędnych i wywiedzionych spoza systemu prawa stanowionego - z prawem wyższym: prawem naturalnym czy tradycją moralną społeczeństwa, a także zasadami racjonalności i słuszności, mającymi wymiar bądź to moralny, bądź ideologiczny. Ów katalog wartości podstawowych stanowiący fundament ustroju zawarty winien być w akcie prawnym nadrzędnej mocy, zwykle zwanym konstytucją (wyraźne odstępstwo stanowi tu właśnie Zjednoczone Królestwo, które - póki co - nie ma spisanej konstytucji). Współczesna praktyka do wartości nadrzędnych zalicza zasady składające się na doktrynę polityczno-prawną liberalnej demokracji, m.in. zasady: (B1) suwerenności ludu, czy też uznania instytucji demokratycznych (lub demokracji reprezentatywnej); (B2) trójpodziału władzy lub innych mechanizmów hamulców $i$ równowagi - w tym: odpowiedzialności politycznej rządu, niezawisłości sądów itd.; (B3) równości wobec prawa i w prawach; a także (B4) respektowania praw człowieka (wolności osobistych, wolności wyznania i przekonań, wolności słowa i zgromadzeń, wolności ekonomicznych). 
Powyższy podział wiąże się rzecz jasna z doktrynalnym podejściem do problemu praworządności (vide A). Ko n c e p cje pozy ty w is t y czn e (ku którym skłania się praktyka prawa) redukują zasadę praworządności do jej formalnego ujęcia. Honorują tetyczny sens obowiązywania prawa, odnosząc się wyłącznie do tego, co w danym systemie jest uznane za jego źródło, czyli zwykle do tego, co pochodzi od ustawodawcy państwowego. Za podstawę do uznania nieważności prawa uznaje się tutaj jedynie zgodne z procedurą uchylenie tegoż. W tym ujęciu wszelkie akty cywilnego nieposłuszeństwa prawu bierze się za zaprzeczenie idei praworządności. Tymczasem (vide B) k o n c e p cje prawno-naturalne - zorientowane wokół aksjologicznego sensu obowiązywania prawa, mówiące, jakie prawo powinno być, a nie tylko wymagające jego przestrzegania, uznają za wiążące zasady słuszności i racjonalności, które nie są zawarte w prawie pozytywnym. $Z$ takiej perspektywy nieposłuszeństwo jakiemuś prawu, w przypadku jego rażącej niezgodności z nadrzędnymi wartościami (tym samym jego nieważności), uznawane jest za zgodne z duchem praworządności (przynajmniej przy spełnieniu pewnych warunków świadczących o słusznej intencji, jak choćby tych opisanych przez Henry'ego D. Thoreau $)^{20}$.

Praworządność zestawić należy z powstałym na gruncie niemieckim pojęciem $\mathrm{p}$ ań stwa prawa lub też (występującego w polskiej konstytucji) państwa prawnego. W przeważającej części literatury jest ono uznane za osobne pojęcie. Nawet jednak w tym przypadku mamy do czynienia z wyraźną analogią, jeśli idzie o podejście doktrynalne.

(A') W historycznie późniejszym, formalno-pozytywis tycznym ujęciu prawo (racjonalny, bezosobowy, więc i doskonale obiektywny porządek) konstytuuje państwo - twór techniczno-prawny: profesjonalny i bezstronny aparat urzędniczy. Państwo jest catościa prawa - jego ucieleśnieniem. Takie państwo-prawo posiada samoistny byt (prawo jest pojęciem z dziedziny jego ontologii, kosmosem jego regut); byt pierwotny wobec społeczeństwa, którym ma zawiadywać - utożsamiane jest z państwem zwierzchnim (Obrigkeitsstaat) i teoretycznie może reprezentować najprzeróżniejsze formy ustrojowe - także te niedemokratyczne w rozumieniu nowożytnym. Jest ono bytem autoreferencyjnym (samookreślającym się w aktach ustawodawcy państwowego); wszelkie ewentualne bodźce społeczne (reprezentacja) ulegają na jego poziomie obiektywizacji i neutralizacji. Ujecie to, szczególnie w wydaniu liberalnym, starało się kategorycznie rozgraniczyć państwo od społeczeństwa - to ostatnie traktując jak arenę hobbesowskiego stanu natury (zakłóconego jeszcze nierównościami społecznymi): świat partykularnych interesów i stronniczych opinii. Państwo, dla kontrastu, miało być z zasady neutralną sferą wolności i formalnej równości; sferą, w której - za sprawą uwalniających od ograniczeń praw osobistych i politycznych - gwarantowana jest podmiotowość i autonomia jednostki (jej osobowość).

(B’) W historycznie wcześniejszym, odtworzonym po II wojnie światowej, u j ęc c i u materialnym pojęcie państwa prawa, czy też państwa praworządnego, traktuje się

20 H.D. Thoreau, Civil Disobedience, [w:] tenże, Walden and Civil Disobedience, New York 2004, s. 265$-286$. 
jako zagadnienie bardziej z dziedziny nauki o państwie niż o prawie, a to przez wzgląd na (wyznawaną w niemieckiej doktrynie prawa) pierwotność państwa względem prawa (prawo należy do państwa) - na to, że nie da się państwa zredukować do praworządności formalnej: prawa, jego mechanizmów i procedur. Jako że ustrój nie jest tożsamy państwu, pojecie państwa prawa należy do zagadnienia ustroju państwa, jego mechanizmów i uwarunkowań ideologicznych, nie zaś do samej ontologii państwa. Takie państwo prawa (tj. państwo demokratyczne) przeciwstawia się więc państwu policyjnemu (Polizeistaat, które nawet w swoim najmniej pejoratywnym sensie jest państwem silnie nadzorczym) i tym samym również państwu zwierzchniemu (Obrigkeitstaadt zwierzchniemu wobec społeczeństwa). W tym ujęciu nie tylko akcentuje się rolę instytucji kontroli legalności działań państwa - odwracając wcześniejszą relację państwa do społeczeństwa (teraz to społeczeństwo nadzoruje państwo). Z namaszczeniem zwraca się tu także uwagę na kwestię społecznego zakorzenienia treści prawa - utożsamia się państwo prawa $\mathrm{z}$ państwem spotecznym, czyli takim, które jest podporządkowane społeczeństwu, ale nie przez przeciwstawienie się mu, lecz przez zawieranie się w społeczeństwie, i to bez wyraźnej linii wyodrębnienia. Społeczeństwo jest w tym ujęciu nie tylko źródłem władzy, ale i władzy wykonawcą. Materialne ujęcie państwa prawa uzupełnia również to formalne w postrzeganiu pozycji ustrojowej jednostki, wprowadzając kategorię praw ekonomicznych, socjalnych i kulturalnych; traktuje ono postulaty sprawiedliwości społecznej i interesu społecznego jako niesprzeczne z dobrem jednostki. Do oglądu tego dodaje bowiem aspekt społeczno-historycznego zakorzenienia jednostki, który w formalistycznym ujęciu był zupełnie ignorowany, a nawet uznawany za szkodzący realizacji idei państwa prawa.

To szkicowe wprowadzenie nada wyraźniejszy kontekst ideom zawartym we Wstępie do nauki o prawie konstytucyjnym.

\section{TRZY CECHY (ANGIELSKIEJ) ZASADY RZĄDÓW PRAWA WEDŁUG A.V. DICEYA}

Supremacja lub rządy prawa zdaniem Alberta Venn Diceya składają się z trzech różnych, choć powiązanych ze sobą idei; znaczeń, rozumień:

(I) Pierwszą ideą składową jest woln o ść (legal freedom) - wolność monteskiuszowska, czyli prawo czynienia wszystkiego tego, na co ustawy pozwalaja, przez wzgląd na to, że gdyby [...] jeden obywatel mógt czynić to, czego one zabraniaja, nie bytby już wolny, ponieważ inni posiadaliby $z$ natury rzeczy tę sama możnośćc ${ }^{21}$. Tak rozumianą wolność opisuje najpełniej znana na kontynencie maksyma, że nie ma kary bez prawa (w tym wypadku: prawa ustanowionego $w$ drodze zwyczajnej procedury, przez zwyczajne sady

21 Monteskiusz, O duchu praw, przeł. T. Boy-Żeleński, posł. S. Łojek, Kraków 2003, s. 147, Wielkie Dzieta Filozoficzne. Dicey cytuje passus z Monteskuisza w przypisie (w tłumaczeniu W.H.): Wolność jest to prawo czynienia wszystkiego tego, na co ustawy pozwalaja: gdyby zaśjeden obywatel mógt czynić to, czego one zabraniaja, nie bytby już wolny, ponieważ inni posiadaliby z natury rzeczy tę sama możność (A.V. Dicey, Wstęp..., s. 120; tenże, An Introduction..., s. 189). 
krajowe). Idea ta przeciwstawia się wszelkiego rodzaju systemom władzy dyskrecjonalnej - władzy szerokiej, nieokreślonej i niekontrolowanej; lub inaczej - zwalcza ona takie systemy, w których ludzie ulegają nie rządom prawa, a wybrykom humoru²2.

(II) Drugą cechą rządów prawa jest równość wobec prawa (legal equality). U Diceya pojawia się sugestia, że izonomia, choć na kontynencie znana, nie przyniosła tam tak dogłębnych konsekwencji ustrojowych. Zagadnienie to będzie wymagało szerszego omówienia w kontekście przeciwstawienia sobie prawa administracyjnego i rządów prawa ${ }^{23}$.

(III) Trzecia idea (znaczenie) rząów prawa w Anglii jest zupełnie obca doświadczeniu mieszkańców Kontynentu. Jest nią, jak ujmuje to Dicey, przewaga zmystu prawnego (predominance of the legal spirit). Zmysł ów polega na tym, że zasady ogólne konstytucyi (takie jak naprzyktad wolność osobista, prawo zebrań publicznych) są u nas rezultatem orzeczeń sadowych, określających prawa obywateli w sprawach poszczególnych, poddanych rozpatrzeniu sądowemu [...]; gdy tymczasem [...] w wielu panstwach obcych gwarancje wynikają lub przynajmniej zdaja się wynikać z ogólnych zasad konstytucji. Nawet statuty (takie jak Bill of Rights) wydane celem zapobieżenia specyalnym naduzyciom, sa wielce podobne od orzeczeń sądowych i sa w rzeczywistości, wyrokami wydanymi przez trybunat parlamentu, przyjmującymi formę potępienia sądowego (konkretnych) uroszczeń i praktyk korony uznanych za bezprawne (podobną formułę zachowało nawet pierwsze dziesięć poprawek do konstytucji USA ${ }^{24}$ ) - to z nich dopiero wnioskuje się o treści zasad konstytucji. Dicey ujmuje to jeszcze dobitniej, biorąc za przedmiot porównawczy królestwo Leopolda II: $W$ Belgii prawa jednostek sa dedukcyami zasad konstytucyi, podczas gdy w Anglii to, co nazywamy zasadami konstytucyi, jest szeregiem indukcyjnych wniosków lub uogólnień, opartych na wyrokach trybunatów w poszczególnych sprawach, tyczacych się wolności danych jednostek ${ }^{25}$.

Żeby wyjaśnić znaczenie czegoś tak charakterystycznego dla angielskiej idei rządów prawa (i z pozoru pobocznego dla rządów prawa w ogólności) jak indukcyjność zasad konstytucyjnych (przeciw ich „dedukcyjności”, wyznawanej na Kontynencie), trzeba będzie w dalszej części nawiązać do pewnego wątku debat z pogranicza polityki, historii i filozofii - debat, których kulminacja przypadła na burzliwy koniec XVIII w.

\section{ROLA ZMYSEU PRAWNEGO W PRAWORZĄDNOŚCI ANGIELSKIEJ}

Dokładniejsze omówienie Diceyowskich rządów prawa warto rozpocząć od trzeciego spośród wymienionych ich aspektów, który zarazem jest najbardziej wyraźnym świadectwem ich angielskiej specyfiki.

22 A.V. Dicey, Wstęp..., s. 119-120; tenże, An Introduction..., s. 189-190. Przedmiot wolności w prawie posiada osobną, obszerną literaturę i nie będzie w tym miejscu szerzej rozwijany.

23 Tenże, Wstęp..., s. 123-124; tenże, An Introduction..., s. 193-194.

24 Tenże, Wstęp..., s. 126 i przyp. na s. 128-130.

25 Tamże, s. 124-126; tenże, An Introduction..., s. 195-197. 


\section{Dzieło rąk ludzkich}

Autor Wstępu..., pisząc o przewadze zmystu prawnego, nawiązuje do zawartej w pracy O rzadzie reprezentatywnym koncepcji Johna Stuarta Milla mówiącej o dwóch odmiennych zapatrywaniach na rząd ${ }^{26}$. Jedno z nich streszcza się w popularnym w Anglii powiedzeniu (przypisywanym Edmundowi Burke’owi), że konstytucya nie zostata stworzona, lecz sama powstata. Dicey gwałtownie protestuje przeciw jego dosłownemu rozumieniu: Konstytucje polityczne sa dzietem rąk ludzkich. Nie znajduje się ich catkowicie dojrzatych, budzac siępewnego, pięknego poranka. W pewnym miejscu jakby podnosi ton: I bynajmniej nie sa one podobne drzewom, które, raz zasadzone rosna, gdy ludzie śpia. W każdej chwili ich bytu świadoma wola ludzka robije tem czem sqa ${ }^{27}$. Dicey skłania się więc do drugiej spośród teorii rządu wyróżnionych przez Milla, która zapatruje się na konstytucję (odtożywszy na bok względna ważność rzeczy) tym samym okiem co na ptug parowy albo na mtocarnię, nie zaś jak na żywy organizm.

Dicey czyni to nie tylko, jakby starał się podkreślić, że mimo wyraźnego doktrynalnego zakorzenienia w prawie natury common law jest tworzone i podlega interpretacji nie rozumu przyrodzonego (natural reason), ale właśnie artificial reason (rozumu sztucznego), który nabywa się w długim i mozolnym procesie studiów, obserwacji i praktyki prawa; a i tak nie jest on dostępny każdemu rozumowi przyrodzonemu. Taki rozum ma charakter inkrementalny, rozwija się przez gromadzenie doświadczeń i to właśnie doświadczenie, próba czasu (a nie logika), jest jego wiążącym kryterium ${ }^{28}$.

Dicey akcentuje rolę prawników, których angielski ustrój obarczył szczególną odpowiedzialnością - czyniąc jednym z niewielu czynników zdolnych przeciwstawić się zapędom monarszego absolutyzmu. Zdaje się w tym miejscu oddawać hołd pokoleniom sędziów, którzy stanęli na wysokości zadania, wykazując niezłomność i hart ducha. Za wzór takiej postawy należy uznać żywot słynnego Williama Gascoigne’a, najwyższego sędziego królestwa z początków XV w., który - jak mówią podania - przeciwstawił się woli następcy tronu, przyszłego króla Henryka V, gdy ten, grożąc mu mieczem, chciał przerwać proces swojego przyjaciela ${ }^{29}$. Ten zmitologizowany przykład - czyniący pre-

26 J.S. Mill, $O$ rządzie reprezentatywnym, [w:] tenże, O rządzie reprezentatywnym. Poddaństwo kobiet, przeł. J. Hołówka, Warszawa 1995, s. 38-69, Demokracja. Filozofia i praktyka.

27 A.V. Dicey, Wstęp..., s. 123-124.

28 Tenże, The Origins of Constitutional Government..., s. 171-187. Twierdzenie to ma swe źródło w słynnej odpowiedzi sędziego Coke’a na pytanie króla, czy do pojęcia prawa nie wystarczy rozum dostępny wszystkim z natury: Prawda to, że Bóg obdarzyt W. Kr. Mość doskonata wiedza i wielkimi darami przyrodzonymi; ale W. Kr. Mość nie jest uczony w prawie swego królestwa angielskiego, a sprawy dotyczące życia lub dziedziczenia albo dóbr lub majątków jego poddanych trzeba rozstrzygać nie przyrodzonym rozumem lecz rozumem sztucznym i osądami prawa, które to prawo jest sztuka wymagająca dtugiej nauki i doświadczenia, zanim cztowiek dojdzie do jejposiadania (M. Szerer, Sądownictwo angielskie, Warszawa 1959, s. 20).

29 Gascoigne miat ponoć powiedzieć: The King has committed all his judical power to divers courts, co miałoby znaczyć, że władza sadownicza samego monarchy stała się wyłącznie nominalna (A. Bryk, Limits of Arbitrary Government..., s. 24). Zob. także: G. Bidwell, Ostatni rycerz króla Artura, przeł. A. Bidwell, Katowice 2005, s. 138-141, „Ksiąznica” Kieszonkowa. 
cedens i doktrynę zarazem - przyświecał późniejszym, w tym Edwardowi Coke’owi (również w roli sędziego), których czyny i słowa kładły podwaliny pod amerykańskie judical rewiew, a przede wszystkim i pierwej - pod zasadę niezawisłości sądownictwa ${ }^{30}$. Dicey pisze o naznaczeniu historii ustroju Anglii ich nazwiskami: znajomość tych wypadków zapobiega co najwyżej ztudzeniu jakoby wspótczesna wolność konstytucyjna byta owocem postępu wstecznego, t.j. powrotu do mądrości naszych przodków barbarzyńskich ${ }^{31}$, a więc w duchu krytycznym, jak się zdaje, wobec co najmniej niektórych wątków wigowskiej historiografii ${ }^{32}$. Wniknięcie w treść wywodów autora wykaże jednak silne uwarunkowanie tą tradycją historiopisarstwa.

Dicey kładzie tutaj silny akcent na główny wątek angielskiego republikanizmu: na to, że mechanizm polityczny nie dziata sam z siebie. Wymaga on nie tylko prostego przyzwolenia, ale i czynnego udziatu ${ }^{33}$. Konkretnie: prawa fundamentalne bynajmniej nie bronią się same ani nie broni ich ktoś inny. Należy o nie walczyć własnymi siłami, na sali sądowej - czasem wielkim kosztem osobistym. Wszak konstytucja angielska nie tylko nie jest w ogóle dzietem prawodawstwa, lecz owocem obrony praw jednostki przed trybunatami. Tak jak rządy sq dzietem ludzkim ${ }^{34}$, tak i konstytucya nasza jest dzietem sędziów (judge-made Constitution); ma ona wszystkie cechy dobre izte prawa, stworzonego przez sędziów (judge-made law) 35 .

\section{Prawa Anglika}

Jako przykład funkcjonowania takiej „sędziowskiej konstytucji”, powstającej w drodze walki w konkretnych sprawach, Dicey podaje kwestię wolności osobistej, która stanowi cześćkonstytucyiponieważjest sankcjonowanąprzezdecyzje trybunatów, któresą rozszerzone lubpotwierdzoneprzez Habe as Corpus ${ }^{36}$. Angielska tradycja prawno-polityczna nie koncentruje się na ustanawianiu kart praw obywatela - spisanych i umieszczonych w ustawie zasadniczej, lecz niemających same w sobie żadnych gwarancji poszanowania (Dicey podaje przykład nagminnie łamanej konstytucji francuskiej z 1791 r.). Tradycja ta ignoruje problem kodyfikacji i zamiast tego ogniskuje swoją uwagę na gwarancjach praw, środkach ich sankcjonowania - w myśl zasady ubi ius, ibi remedium. Widać wyraźnie, że to właśnie w Diceyowskim zmyśle prawnym Anglików zawierają się procedu-

30 Zob.: A. Bryk, The Origins of Constitutional Government..., s. 189-210. Także: tenże, Limits of Arbitrary Government...

31 A.V. Dicey, Wstęp..., s. XIV.

32 Zob. szczególnie uwagi Burke’a: E. Burke, Rozważania o rewolucji we Francji. I o debatach pewnych towarzystw londyńskich związanych z tym wydarzeniem, wyrażone w liście, który miat zostać wystany do pewnego gentlemana w Paryżu, przeł. D. Lachowska, wstęp P. Kłoczowski, Kraków-Warszawa 1994, s. 50, Demokracja. Filozofia i praktyka.

33 J.S. Mill, O rzadzie reprezentatywnym, s. 40.

34 Tamże, s. 38.

35 A.V. Dicey, Wstęp..., s. 125. Wyróżnienie w oryginale.

36 Tamże, s. 126. Wyróżnienie w oryginale. 
ralne gwarancje praworządności, czyli ostatniej spośród pięciu wymienionych na wstępie cech formalnej praworządności (Uwagi wprowadzające: A5).

Natrafiamy znów na kwestię osobistej walki obywateli (narodu politycznego) na salach sądowych o skuteczne zabezpieczenia praw. Tutaj rysuje się kontekst, w jakim właściwego znaczenia nabierają uwagi Edmunda Burke’a i Hannah Arendt o wyższości praw Anglika nad prawami cztowieka. Angielski zmyst prawny akcentuje właśnie kwestię praktycznych mechanizmów obrony praw. Podejrzliwie spogląda więc na darowanie ich lekką ręką, kreślącą kilka pięknych słów na papierze. Dla Burke’a wolność cztowieka rozpatrywana sama w sobie - w nagości i wyizolowaniu wtaściwym metafizycznej abstrakcji - tak jak władza państwowa, nie zasługuje na krytykę. Ale powstrzymał się on z gratulowaniem Francuzom ich świeżej wolności do chwili, gdy dowiemy sie jak powiazano ja z wtadza panstwowa, ze środkami przymusu, $z$ dyscyplina i innymi instytucjami obywatelskimi i społecznymi ${ }^{37}$. Uwagi te rozwija Hannah Arendt w tragicznym kontekście Holokaustu, a szczególnie kwestii apatrydów - ludzi odartych ze swojej przynależności państwowo-narodowej, czyli pozbawionych wszelkich gwarancji prawnych - okrojonych do swojej nagiej abstrakcyjnej osoby ludzkiej ${ }^{38}$. Prawa Anglika mają tę wyższość nad prawami cztowieka, że w istocie są tych ostatnich instytucjonalnymi gwarancjami; a są Anglika, ponieważ to Anglicy je sobie wywalczyli, w ramach swoich narodowych instytucji.

W tym miejscu warto przytoczyć znamienne zdanie dotyczące szczególnej procedury sądowej (tzw. writ of habeas corpus) służącej testowaniu prawnej zasadności pozbawienia wolności: Ha be as Corpus nie gtosi żadnej zasady, nie określa żadnego prawa, w praktyce jednak wart [jest] więcej, niz setki artykutów konstytucyjnych, gwarantujących wolność osobistą ${ }^{39}$. Jak się przekonamy dalej, habeas corpus najlepiej ilustruje wyjątkowość angielskiej wersji supremacji prawa. Nie tylko jest przykładem żywej, sędziowskiej konstytucji (idea trzecia rule of law). Jako takie wyrasta także z palącej potrzeby powściągnięcia zakusów władzy monarszej, chcącej działać wedle swojego „widzimisię" (idea pierwsza), a także w najgłębszy z możliwych sposobów realizuje ideę równości (drugą) - iżby nikt nie był ponad prawem.

\section{Indukcyjna konstytucja}

Rozwijając wątek, Dicey zauważa, że z punktu widzenia angielskiego prawnika niezrozumiałe jest stwierdzenie zawarte w konstytucjach kontynentalnych, iż są jakieś prawa (zwane fundamentalnymi) bardziej od innych gwarantowane $e^{40}$. Warto zastanowić się nad sensem takiego poglądu, szczególnie w kontekście uznawania przez Diceya doktryny suwerenności parlamentu. Oczywiste jest, że gradacja reguł nie jest stosowna dla sys-

E. Burke, Rozważania o rewolucji..., s. 28.

38 H. Arendt, Korzenie totalitaryzmu, t. 1, przeł. M. Szawiel, D. Grinberg, Warszawa 1993, s. 334-336, Krytyka.

39 A.V. Dicey, Wstęp..., s. 128. Wyróżnienie w oryginale.

40 Tamże, s. 129. 
temu prawnego pozbawionego pisanej konstytucji i tym samym takiego, którego prawo konstytucyjne - używając słów Maitlanda - nie posiada żadnej wyjątkowej nienaruszalnościti . Można natomiast zauważyć, że prawo to, wedle założeń jednej z interpretacji, ma być komplementarnym systemem, rządzonym przez pewną logikę (maksymy prawa, formalna moralność prawa) i ducha (prawo naturalne) - tym samym jedynie interpretowanym i uszczególawianym w toku orzecznictwa trybunałów i parlamentu. W takim systemie zakłada się raczej - tak jak to czynił Edmund Coke w przypadku sprawy doktora Bonhama z $1610 \mathrm{r}^{42}$ - że naruszenie praw obywateli przez przedstawicieli władzy, a nawet przez ustawodawcę, wynikać może jedynie z mylnej interpretacji prawa i/lub niekonsekwencji, a zatem błędów biorących się z niewiedzy - nie zaś z umyślnego nadużycia władzy przez suwerena, intencjonalnie naruszającego zasady dla swoich pozaprawnych celów (wszak wiadome jest, że król nie może czynić źle, także $w$ Parlamencie, czyli ustanawiając prawa).

Mówiąc jednak o pozaprawnym kryterium odniesienia prawa, pamiętać musimy, że w Diceyowskim - pozytywistyczno-prawnym - oglądzie rzeczy parlament jest suwerenem (władcą absolutnym i nieograniczonym), a tym samym także twórcą prawa w rozumieniu ścisłym, nie zaś jakimś interpretatorem prawa wyższego rzędu, na równi $\mathrm{z}$ sędziami. Tutaj konstytucja jest niejako rzeczą wtórną względem faktycznego generalnego kształtu ustawodawstwa, a także praktykowanych zwyczajów konstytucyjnych. Perspektywa taka funduje doktrynę, dla której problem naruszenia prawa przez jego funkcjonariuszy (wbrew ich faktycznej władzy), a nawet przez nowe prawodawstwo, uznaje się raczej za kwestię czysto techniczno-prawną, nie zaś polityczną. Sędziowie w tym sensie nie mają oczywiście żadnego prawa obalania ustaw przez stwierdzenie ich sprzeczności z prawem naturalnym (zasadami moralności prywatnej i publicznej). Coke'owska frazeologia kontroli i stwierdzania nieważności aktów parlamentu (jak i ta Blackstone'owska, mówiąca, że wszelkie prawa czerpią swą moc z prawa naturalnego) nie oznacza $w$ rzeczywistości nic innego, jak tylko to mianowicie, że sędziowie wychodza zzatożenia, że parlament nie miat zamiaru gwatcić zwyczajnych regut mo raln ości, ani tez zasad prawa międzynarodowego; w konsekwencji więc nadaja. rozporządzeniu prawodawczemu znaczenie, o ile możności, dające siępogodzić z normami moralności prywatnej i prawa międzynarodowego. Toteż, generalnie rzecz ujmując, konstytucya jest rezultatem zwyktego prawa krajowego ${ }^{43}$.

$\mathrm{Z}$ powyższego wynika m.in., że dostępny parlamentowi brytyjskiemu akt zawieszenia habeas corpus nie oznacza - jak na Kontynencie - zawieszenia obowiązywania zasady wolności osobistej, a jedynie zawieszenie jej gwarancji (środka jej egzekucji), czyli zawieszenie wydawania przez sądy writu habeas corpus (wzywającego np. szeryfa do wykazania prawnej podstawy pozbawienia wolności). Dla Anglików zawieszenie takiej tkwiącej w zwyczajem prawie krajowym wolności jako takiej (tożsame de facto z tymcza-

\footnotetext{
${ }^{41}$ Cyt. za: Stownik politologii, red. B. Walicka, Warszawa 2008, s. 460 [na podstawie: Concise Dictionary of Politics, Oxford 2003].

42 Zob.: A. Bryk, Limits of Arbitrary Government..., s. 74.

43 A.V. Dicey, Wstęp..., s. 21, 131. Wyróżnienie własne autora.
} 
sowym jej zniesieniem) oznaczałoby rewolucję: zupetny przewrót w instytucjach i zwyczajach narodu ${ }^{44}$.

Ustawy zawieszające habeas corpus (Habeas Corpus Supension Acts) nie tylko nie znoszą obowiązywania wolności osobistych, ale również - a raczej przede wszystkim: nie znoszą ogólnego prawa do writu habeas corpus. Zawieszenie owo wcale nie upoważnia władzy do bezprawnego aresztowania i wymierzania nielegalnych kar; nie uwalnia nikogo od odpowiedzialności cywilnej i karnej za przekroczenie prawa. Jedyne, co czyni, to - na czas „przesilenia politycznego” - opóźnienie dostarczenia przed sąd aresztowanego za zdradę stanu i tym samym uzyskania przez niego zwolnienia i wyznaczenia terminu rozprawy. Tak więc, gdy ustaje owo zawieszenie, niesłusznie aresztowany może w drodze procedury habeas corpus uwolnić się i doprowadzić do ukarania wszystkich odpowiedzialnych za jego krzywdy.

Fakt, że niesłuszne aresztowanie dokonane było w czasie zawieszenia habeas corpus, nie jest tu żadną wymówką. Łamiących prawo funkcjonariuszy uratować od zguby może dopiero osobny gest: parlamentarny akt łaski, w formie ustawy zwanej Act of Indemnity - mającej na celu legalizacye czynności, która w chwili wykonania byta nielegalna, lub też uwolnienie od odpowiedzialności jednostek winnych przekroczenia ustaw, a stanowiącej naoczny dowód obowiązywania w Zjednoczonym Królestwie zasady suwerenności parlamentu. Stanowi ona w zamyśle amnestię, oczyszczającą z odpowiedzialności zwykłych obywateli i funkcjonariuszy państwa, którzy w dobrej wierze i w trosce o dobro publiczne postąpili wbrew prawu $^{45}$. W praktyce na takie ułaskawienie należy dopiero liczyć w przyszłości, bowiem żadne prawo angielskie nie zapewnia nikomu nietykalności na przyszłość - dając wolną rękę do łamania prawa ${ }^{46}$.

Indemnity Act jest oczywiście dla Diceya żywym świadectwem obowiązywania suwerenności parlamentu, lecz dla niego ta ostatnia jest tylko pozornie sprzeczna z ideą rule of law - drugą kierownicza zasada catej konstytucji angielskiej. W istocie, zasady te są ze sobą nierozerwalnie sprzężone.

Po pierwsze, wynika to ze szczególnego traktowania ustaw przez sędziów, którzy stosując je, zupełnie ignorują pierwotne i faktyczne intencje prawodawców, a baczność mają na ich literalną treść i na doktrynę. Charakter wykładni - sprawiającej wrażenie nad wyraz ciasnej - upoważnia do stwierdzania, że parlament, wydając akt swojej woli (ustawę) i powierzając go judykaturze, najzupełniej traci nad nim kontrolę. Wówczas przejmują ją sędziowie kierujący się ogólnym duchem common la w’u ${ }^{47}$.

44 Tamże, s. 130.

45 Zob.: tamże, s. 9-11. W latach od 1727 do 1828 na przykład procedura ta służyła do obejścia surowych zasad religii państwowej - do legalizacji pełnienia urzędów publicznych przez osoby nienależące do Kościoła anglikańskiego, co było ustawowo zakazane (w formie reguł pierwotnych, nie wtórnych).

46 Tamże, s. 152-159.

47 W tym miejscu wypada przypomnieć ciekawą uwagę Maxa Webera: Przyczyna porażki wszelkich prób kodyfikacji, a także recepcji prawa rzymskiego byt $w$ Anglii skuteczny opór jednolicie zorganizowanych duzych cechów adwokatów, monopolistycznej warstwy notabli, z której szeregów wywodzili się sędziowie znaczacych sądów (M. Weber, Gospodarka i Spoteczeństwo. Zarys socjologii rozumiejącej, przeł. i wstęp D. Lachowska, Warszawa 2002, s. 708, Biblioteka Socjologiczna). Zdanie to podsu- 
Po drugie, kluczową jest sama struktura suwerennej instytucji - to, że rozkazy Parlamentu nie moga być inaczej wykonane, jak tylko za pomoca skombinowanej akcyi trzech czynników prawodawczych: Królowej, Izby Gmin i Izby Lordów. Dzięki temu nie ma w Anglii żadnego samoistnego podmiotu suwerenności. Nie jest nim ani monarcha, ani żadne z ciał zbiorowych samodzielnie - żaden z reprezentowanych w nich interesów stanowych (klasowych) nie może zdominować pozostałych. Odpowiada to statusowi ustawodawcy w ujęciu pozytywistycznej doktryny państwa prawnego, na poziomie którego wszelkie bodźce społeczne, w wyniku procesu reprezentacji, mają ulec obiektywizacji i neutralizacji (tak by nie można już było powiedzieć, że dane prawo jest $c z y j e s ́$ ). Widzimy tu wręcz pewne aspekty przypisywane zwykle formalnej koncepcji państwa prawa (Uwagi wprowadzajace: A').

$\mathrm{Z}$ toku wywodu można - choć Dicey nie pisze tego wprost - wywnioskować, że suweren w Zjednoczonym Królestwie nie powinien być postrzegany jako pewne gremium (mające masę członkowską), ale raczej jako określona regułami wirtualna przestrzeń posiedzeń tegoż. Fakt, że suwerenny parlament nie posiada substancjalnie istniejącego desygnatu, a ma w istocie charakter pewnej procedury (bytu relacyjnego), tym bardziej wzmacnia rolę sędziów i całej tradycji common law ${ }^{48}$. Pro o e du ralny charakter brytyjskiej suwerenności (prawnej), w kombinacji ze swoistą a li e n a cją p ra $\mathrm{w}$ a od jego pomysłodawców umożliwia realizacje abstrakcyjnej zasady rule of law $\mathrm{w}$ duchu formalno-pozytywistycznego państwa prawa - także jako państwa zwierzchniego wobec społeczeństwa, nawet pomimo tak silnego uwarunkowania prawa przez opinię publiczną (suwerena politycznego).

\section{Podsumowanie}

Pisząc o angielskim „zmyśle prawnym” - o roli woli ludzkiej, szczególnie zaś sędziów w formowaniu konstytucji (acz nie w sensie dosłownym); o gwarancjach praw Anglika i o indukcyjnym postrzeganiu konstytucji - Dicey zdaje się iść ścieżką (jak można przypuszczać) szczególnie lubianą przez anglosaskich prawników, na której to ich korporacja zawodowa jawi się zbiorowym bohaterem anglo-amerykańskiej historii; ścieżką modelu konstruktywistycznego, stanowiącą zarazem ideę przewodnią ich etosu zawodowego; ścieżkę, którą Ronald Dworkin (co ciekawe, przeciwnik pozytywistycznego podejścia) opisał jako właśnie owo indukcyjne poczucie odpowiedzialności za spójność z tym, co zaszto wcześniej ${ }^{49}$. W tym właśnie aspekcie Wstępu do nauki prawa konstytucyjnego dostrzega się nieortodoksyjność pozytywizmu Diceya ${ }^{50}$.

mować można wnioskiem, iż w Anglii zamiast rządów prawa (rule of law), panują raczej $r z a d y$ prawników (rule of lawyers).

48 A.V. Dicey, Wstęp..., s. 254-261.

49 R. Dworkin, Biorac prawa poważnie, przeł. T. Kowalski, Warszawa 1998, s. 295, Biblioteka Wspótczesnych Filozofów.

50 T.R.S. Allan, Dworkin and Dicey. The Rule of Law as Integrity, „Oxford Journal of Legal Studies” 1988, Vol. 8, nr 2, s. 266-277. 
Tutaj - by nie ulec pewnemu złudzeniu - wskazać należy na zasadniczą dla konstytucji angielskiej konsekwencję jej indukcyjnego charakteru. Otóż owa duma z treści angielskiej konstytucji, przebijająca z niemal każdej stronnicy dzieła Diceya, nie wiąże się z żadnymi konsekwencjami normatywno-prawnymi (choć niekoniecznie moralny$\mathrm{mi}$ ), tj. z ewentualnym potępieniem czy nielegalnością aktów sprzecznych z angielską niepisaną konstytucją.

Dicey wyjaśnia rzecz - w gruncie rzeczy na marginesie swojej pracy, bo w przypisie poruszając kwestię tego, co należy rozumiećprzez prawo „niekonstytucyjne”. Wyróżnia on trzy znaczenia tego terminu: (1) Pierwsze, właściwe tradycji angielskiej, stwierdza, że dany akt parlamentu jest zwyczajnie sprzeczny z duchem konstytucji, bez przesądzania, czy jest on prawem, czy też gwałci jakieś prawo. Wynika to z faktu szczególnego charakteru naczelnych zwyczajów konstytucyjnych (ustrojowego uzusu), które w żadnej mierze nie mają charakteru normy prawnej - brak im przede wszystkim sankcji ${ }^{51}$. (2) Drugie - typowe dla Francji (a także Polski) - zawiera w sobie pewne pejoratywne nacechowanie (sugerujące naganę), a znaczące jedynie tyle, że dane prawo jest niezgodne z jakimś paragrafem konstytucji. Prawo takie może mieć jednak status prawa, jeżeli tylko zostanie uchwalone przez legislatywę. Współcześnie jest tak przynajmniej do czasu stwierdzenia niekonstytucyjności przez odpowiedni trybunał (zasada domniemania konstytucyjności). (3) Ostatnie to zastosowanie spotykane w USA, znaczące, że akt wykracza poza zakres kompetencji danego organu (ultra vires) i tym samym nie jest prawem; choć wcale nie zawiera elementów nagany (można powiedzieć: dane rozwiązanie jest jak najbardziej stuszne, lecz niestety jest ultra vires $)^{52}$.

Wedle Diceya więc dla każdego brytyjskiego prawnika stwierdzenie, że jakieś prawo jest niekonstytucyjne, wcale nie powinno oznaczać potępienia ani nawet uznania za nielegalne - a jedynie wskazywać na fakt pewnej jego nieprzystawalności do konstytucyjnej tradycji ustroju. Podkreślić należy, że ów brak wartościowania, n i e n o r m a tywne rozumienie pojęcia niekonstytucyjności, jest wyraźnie główną konsekwencją indukcyjnego charakteru konstytucji angielskiej. Uniemożliwia jej on pełnienie takiej roli, jaką pełnią konstytucje francuskie - prawa zasadniczego, hierarchicznie nadrzędnego (w sensie pozytywnym i negatywnym). Charakter ten czyni z niej bowiem fakt e m piryczny - tym samym wnioskowanie z niej o tym, jaka jest prawna powinność, byłoby rzeczą nieadekwatną.

\section{RZĄDY PRAWA A IDEA PRAWA ADMINISTRACYJNEGO}

Najciekawszym, a za razem najbardziej kontrowersyjnym z wniosków, jakie Dicey wysnuł w 1885 r. podczas swoich rozważań o rule of law, jest ten stwierdzający, że sys-

51 Zob.: A.V. Dicey, Stosunek między prawem konstytucyjnem a zwyczajami konstytucyjnymi, [w:] tenże, Wstęp..., s. 265-310.

52 Tenże, Wstęp..., s. 369-370. Godne odnotowania w tym miejscu wydaje się, iż powyższa typologia sugeruje - wbrew pierwszemu wrażeniu - że konstytucja nie jest w tradycji amerykańskiej tożsama politycznej moralności. 
temowi angielskich rządów prawa obca jest - a wręcz z nim sprzeczna - idea prawa administracyjnego - przynajmniej tego w wydaniu francuskim, mimo że będącego wzorem dla innych państw Kontynentu. Teza ta z czasem stała się cechą rozpoznawczą Wstęp do nauki o prawie konstytucyjnem i do tego stopnia zrosła się z tematem prawa administracyjnego w Wielkiej Brytanii, że pisząc o nim, trudno się do niej nie ustosunkowaćs3.

Jak zauważa Emlyn C.S. Wade, żaden z fragmentów dzieła Diceya nie był tak zajadle atakowany. Wnikliwa krytyka, jakiej poddane zostało twierdzenie o niepraworządności prawa administracyjnego, nie będzie przedmiotem niniejszego wywodu ${ }^{54}$. Będzie nim natomiast prezentacja toku rozumowania Diceya i próba wskazania zakresu jego zasadności. Żeby jednak nie dać się porwać sugestywności wywodów wiktoriańskiego konstytucjonalisty, w swoim miejscu wskazane zostaną najważniejsze z wysuwanych przez komentatorów błędy i nieścisłości.

Pierwotna kategoryczność stanowiska Diceya wynikała częściowo ze statyczności oglądu sprawy, szczególnie w kontekście wielu uwag na temat ewolucji prawa administracyjnego: $\mathrm{z}$ jednej strony przeobrażeń, jakim zostało poddane na Kontynencie; z drugiej zaś jego postępującego zaszczepiania w Anglii (co sam autor przyznaje i koryguje już w przypisach i Dodatkach do wydania szóstego z 1902 r. $)^{55}$. Pomimo jednak wspomnianej krytyki i dezaktualizacji tezy naczelnej uwagi Diceya - nawet jeśli były prawdziwe tylko wedle stanu rzeczy A.D. 1848 - pozostają inspirujące w samym kontekście rozważań na temat idei rządów prawa, nawet w odniesieniu do współczesności.

Przemyślenia autora Wstępu... stanowią też ważny przyczynek do badania historii prawa administracyjnego na Zachodzie. Mają one tę szczególną zaletę, że śladami Alexisa de Tocqueville’a - rysują szeroką panoramę rozwoju zachodniej praktyki funkcjonowania państwa. Panorama ta może jest zbyt szeroka i jedynie szkicowa, gubi wiele istotnych detali, lecz wskazuje problem korzeni, pierwotnych znaczeń, aktualnych funkcji oraz pewnych fundamentalnych mechanizmów, jakim podlegają najważniejsze i wszechobecne instytucje społeczno-polityczne. Jej bliższe zbadanie przedstawia - jakby to ujął sam Dicey - szczególniejszy interes teoretyczny.

Dla zidentyfikowania zasad naczelnych prawa administracyjnego i charakteru tegoż w obliczu pojęcia rządów prawa Dicey porusza newralgiczną kwestię nadużywających władzy funkcjonariuszy. Zanim jednak to zrobi, wyjaśnia, co rozumie przez pojęcie prawa administracyjnego.

53 Zob. choćby: hasło „Prawo administracyjne” w oksfordzkim Stowniku politologicznym (Stownik politologii, s. 457).

54 Zob.: E.C.S. Wade, Appendix, [w:] A.V. Dicey, An Introduction..., s. 475-546.

55 Zob. szczególnie: A.V. Dicey, Wstęp..., s. 229, przyp. 1. Zob. także przyznanie się do inspiracji Tocquevillem, który sam w temacie francuskiego prawa administracyjnego był zorientowany jedynie pobieżnie (dzięki wyjaśnieniom listowym z 1831 r. pewnego urzędnika francuskiego nazwiskiem Blosseville): tamże, s. 230 . 


\section{Pojęcie prawa administracyjnego i powody jego sprzeczności z ideą rządów prawa}

Dicey na potrzeby wywodu ukuwa z dostępnych definicji francuskiego prawa administracyjnego własną. Droit adminstratif jest to ta cześć prawa francuskiego, która określa: 1-o potożenie i odpowiedzialność urzędników; 2-o prawa i obowiazki obywateli w stosunku do funkcjonaryuszów, reprezentujących państwo; 3-o procedurę przy pomocy której prawa te i zobowiazania sq uskuteczniane ${ }^{56}$. Pisząc of fatszywym pojęciu Anglików o "prawie administracyjnem", zauważa że prawo administracyjne, takie jakie istnieje we Francyji nie jest zbiorem upetnomocnień i czynności wykonywanych przez administracye - w przeciwieństwie do często z nim utożsamianymi tzw. official law (prawem służby cywilnej) czy szerzej rozumianym governmental law (prawem rządowym), które są prawami klasowymi. Droit adminstratif [...] to raczej zbiór zasad, rządzacych stosunkami pomiędzy obywatelami francuskiemi, t.j. jednostkami a administracya, reprezentująca państwo, i w tym sensie nie jest wiążące erga omnes ${ }^{57}$.

Taka definicja została przez późniejszych komentatorów, zarówno angielskich, jak i francuskich, uznana za niewystarczającą, gdyż redukowała pojęcie prawa administracyjnego - śladami francuskich teoretyków sprzed 1848 r. - do jednego jego aspektu, konkretnie: jurysdykcji administracyjnej (contentieux administratif), nie uwzględniając

56 Tamże, s. 232. Definicję tę warto porównać z innymi definicjami prawa administracyjnego. Zarówno Jan Boć, jak i Jan Zimmermann przytaczają najbardziej ogólną (ujęcie przedmiotowe) definicję prawa administracyjnego, określającą je jako gatąź prawa, zespót norm regulujących dziatalność administracyjna (administrację w sensie przedmiotowym); lub prościej i szerzej [...], jako [...] prawo, które normuje administracjępubliczna (Z. Cieślak). Definicja taka w realiach współczesnych, w których administracja $\mathrm{z}$ definicji jest normowana prawem, popada w błędne koło. Boć wskazuje na definicję formułowaną $\mathrm{z}$ innego ujęcia (zwracającego uwagę na jego specyfikę): prawem administracyjnym jest to prawo, które zwiera element wtadztwa, tj. daje możliwość jednostronnego rozstrzygnięcia. W niemieckiej nauce przedmiotu (ujęcie organizacyjne) prawo administracyjne normuje [...] ustrój administracji publicznej, a także swoiste formy $w$ których organy te reguluja wtadczo uprawnienia obywatela. Współcześnie określa się to prawo jako system norm prawnych, które w specyficzny sposób obowiazują administrację dziatalność administracji. Prawo to wiąze organy administracyjne i organizacje administracji. Prawo to wiąze organy administracyjne i dotyczy ich dziatalności, ale o wiele bardziej reguluje stosunki między administracja, a obywatelem $i$ tym samym uzasadnia prawa i obowiazki obywatela, lecz tylko $w$ odniesieniu do jego stosunku $z$ administracja (H. Mauer). Francuzi z kolei ujmują zagadnienie funkcjonalnie, podkreślając rolę administracji jako służby publicznej. Tutaj prawo administracyjne określa sposób i cel działania osób prawa publicznego w interesie publicznym. W polskiej nauce prawa administracyjnego rozwinięta została (już od 1917 r., przez Tadeusza Hilarowicza, Jerzego Stefana Langroda i Franciszka de Longchampsa) definicja następująca: prawo administracyjne dotyczy administracji publicznej (pojętej jako pewna dziedzina kultury spotecznej) i jest dla niej swoiste, tj. obejmuje to, co jest wytworzone dla organizacji i dziatania administracji publicznej, a nie zarazem dla innych dziedzin kultury spotecznej. Langrod podkreśla w tym miejscu zasadę działania w granicach prawa i niezależną kontrolę legalności, a Longchamps akcentuje ukierunkowania administracji na realizację dobra wspólnego (J. Zimmermann, Prawo administracyjne, Warszawa 2008, s. 32-34, Seria Akademicka; Prawo administracyjne, red. J. Boć, Wrocław 2007, s. 34-36). W oksfordzkim Stowniku politologii z kolei widać powierzchowne, acz wyraźne, dystansowanie się od definicji Diceya przez uznanie jej za prawo odnoszące się do kontroli wtadzy rządu, w tym również szczegótowe zasady określające przebieg procesu podejmowania decyzji administracyjnych (Stownik politologii, s. 457).

57 A.V. Dicey, Wstęp..., s. 389-390. 
całości, której przedmiotem jest administracja w ogóle. Nieścisłość ta jest o tyle niefortunna, że poglądy Diceya w tym zakresie miały tak przemożny wpływ na całe pokolenia teoretyków prawa w Wielkiej Brytanii i poza nią ${ }^{58}$.

Autorska definicja Diceya stanowi pierwszy element jego rozumowania. W tym miejscu nad jej niepełnością można przejść do porządku dziennego, biorąc ją jako pewne szczególne ujęcie tematu. Dla Diceya bowiem to właśnie problem konfliktu obywatela z urzędem ujawniał najpełniej rysy charakterystyczne prawa administracyjnego i jego relację do angielskiego pojmowania prawa i praworządności. Akcentował on, podobnie jak Władysław Leopold Jaworski w swojej Nauce prawa administracyjnego, znaczenie sądownictwa administracyjnego i - podobnie jak ten polski myśliciel, tyle że nie czyniąc tego expressis verbis - określał tym mianem kontrolę legalności działań administracji, prowadzoną z inicjatywy jednostek, zarówno przez same urzędy, jak też osobne, utworzone do tego sądy - czyli zarówno w ramach postępowania administracyjnego, jak i sądowo-administracyjnego ${ }^{59}$. Nie uznawał natomiast za sądownictwo administracyjne praktyki kontroli prawno-administracyjnej w wydaniu sądów powszechnych.

Naczelna teza Diceya brzmiała tak: Prawo administracyjne, mówiac pokrótce, opiera się na dwóch pojęciach catkiem obcych prawu angielskiemu. Popierwsze, że stosunkami jednostek z państwem rządza zasady zupetnie inne, niż te, którym podlegaja prawa osób prywatnych między sobą. Podrugie, że wszystko, co się tyczy stosowania tych zasad, nie wchodzi w zakres kompetencyi trybunatów sądowych; o tem rozstrzygać maja trybunaty specjalne, które jakkolwiek o charakterze mniej więcej administracyjnym, jednak dobro publiczne bardziej będa miaty na względzie, niż sądy sprawiedliwości ${ }^{60}$.

\section{Rozdział władz}

Zdaniem Diceya cechą specyficzną systemów uznających prawo administracyjne jest założenie o konieczności rozdziatu wtadz, idei zaczerpniętej z pism Monteskiusza,

58 E.C.S. Wade, Appendix, [w:] A.V. Dicey, Introduction..., s. 475, 481.

59 Stanowisko Diceya, upatrujące zakorzenienia prawa administracyjnego we francuskim absolutyzmie, warto skonfrontować z definicją prawa administracyjnego autorstwa Władysława Leopolda Jaworskiego: Jako istotne znamię prawa prywatnego należy przyjąc, że kontrole jego wykonywa państwo, a jako istotne znamię prawa publicznego, że kontrolę wykonywa jednostka. [...] $Z$ takiego pogladu wycho$d z a c$ nazwiemy prawem administracyjnem to prawo, które reguluje dziatalnośćpaństwa, a którego kontrola należy do jednostki. Zrozumiemy znaczenie „kontrola”, jeśli powiemy, że w państwie absolutnym nie ma prawa administracyjnego wtaśnie dlatego, że tam kontrola nad dziatalnością państwa nie przystuguje jednostce (W.L. Jaworski, Nauka prawa administracyjnego. Zagadnienia ogólne, Warszawa 1924, s. 8, 14). Wielka waga, jaką Jaworski przywiązuje do pojęcia kontroli prawa (szczególnie sądowej) - bez której prawo po prostu nie istnieje - a także pierwszorzędne miejsce zagadnienia sądownictwa administracyjnego w toku jego wywodu o prawie administracyjnym zasługują na zestawienie z analogicznymi poglądami Diceya w tym względzie. Zwraca na to uwagę Zimmermann i dodaje, że [w] ten sposób przez pewną skrajność swojego podejścia W.L. Jaworski już ponad 80 lat temu uchwycit lapidarnie najważniejsza cechę tego prawa, jaka jest regulowanie relacji między państwem a jednostka (J. Zimmermann, Prawo administracyjne, s. 33). 
który - co podkreśla autor Wstępu... - i tak zupełnie opacznie zrozumiał rozwiązania ustroju angielskiego w tym zakresie ${ }^{61}$; idei, która dodatkowo została wdrożona we Francji w jeszcze bardziej wykoślawionej formie. Podczas gdy źrenicą systemu angielskiego - faktyczną gwarancją rządów prawa - jest wyłącznie niezależność sę $\mathrm{d}$ z ió w, przy ich stałej możności paraliżowania działań egzekutywy (przede wszystkim za pomocą writa of habeas corpus) ${ }^{62}$, we Francji podział władz między egzekutywą a judykaturą przeprowadzony jest niejako symetrycznie: nie tylko wpływ władzy wykonawczej na sądownictwo jest ograniczony, ale i wpływ sądów na kwestie rządzenia jest znikomy (i był jeszcze na długo przed Wielką Rewolucją) ${ }^{63}$. $Z$ tego względu, podczas gdy w Anglii sądy powszechne same wyznaczają sobie zakres kompetencji ${ }^{64}$, we Francji zwyczajne trybunaty nie sq wtaściwa wtadza sądowa dla spraw rozstrzyganych na mocy prawa administracyjnego, czyli dla spraw z zakresu działalności administracji - nie mogq wyrokować o czynach funkcyonaryuszów wyższych i niższych, dokonywanych przez nich wich charakterze urzędowym ${ }^{65}$.

Najdobitniej wyrażał tę zasadę art. 75 konstytucji francuskiej z 1799 r., który kategorię agentów rządowych wyłączał domyślnie spod jurysdykcji sądów zwyczajnych: Agenci rządowi, inni niż ministrowie, nie moga byćścigani za czyny popetnione w zwiazku $z$ wykonywaniem ich funkcji, jak tylko na mocy postanowienia Rady Stanu; w którym to przypadku orzecznictwo należy do trybunatów zwyczajnych ${ }^{66}$. Ustanawiał on tym samym praktyczną nieodpowiedzialność urzędnika za niezgodny z prawem czyn urzędu kontrolerem jego poczynań czyniąc wyłącznie organ zwierzchni. Ta nieznana w Anglii zasada nieingerencji sądów powszechnych w działania z zakresu aktów rządowych - bliżej nieokreślonych, do których wyróżnienia, w oczach pewnych jurystów, wystarczy, by czyn był spetniony przez egzekutywe i natchniony pobudka polityczna ${ }^{67}$ - zmniejsza, przynajmniej w oczach Anglików, wptyw moralny catego ciata sadowego i pozbawia sprawiedliwość francuska tej powagi, jakq zdobyty trybunaty angielskie, korzystając z niezaprzeczonego prawa interwencyi - pośredniej coprawda, lecz nie mniej przecież skuteczniej $-w$ sprawach tyczacych siępaństwa ${ }^{68}$.

61 Por.: Monteskiusz, $O$ duchu praw, s. 148-156.

62 A.V. Dicey, Wstęp..., s. 246.

63 Warto w tym miejscu przytoczyć słowa Tocqueville'a: Nie byto kraju w Europie [przed Rewolucja], gdzieby sądy ogólne mniej zależaty od rzadu, jak we Francyi; lecz nie byto też kraju gdzieby sady wyjątkowe [administracyjne] byty w takiem uzyciu (A. Tocqueville, Dawne rządy i rewolucja, przeł. W.M. Kozłowski [opracowanie z zachowaniem obowiązujących w 1907 r. zasad pisowni i interpunkcji], Warszawa 2003, s. 55, Arcydzieta Wielkich Myślicieli). Zob. także: A.V. Dicey, Wstęp..., s. 60.

64 A.V. Dicey, Wstęp..., s. 394.

65 Tamże, s. 237.

66 Tłumaczenie własne z: Article 75. Les agents du Gouvernement, autres que les ministres, ne peuvent être poursuivis pour des faits relatifs à leurs fonctions, qu'en vertu d'une décision du Conseil d'Etat: en ce cas, la poursuite a lieu devant les tribunaux ordinaires, [online] http://fr.wikisource.org/wiki/Constitution_ du_13_décembre_1799, 28 XI 2012.

67 A.V. Dicey, Wstęp..., s. 393.

68 Tamże, s. 244-245. 
Oczywiście obywatel ma możność dochodzenia swoich roszczeń w sprawach o krzywdy doznane za sprawą bezprawnych działań funkcjonariuszy publicznych (poczynając od spraw o niedotrzymanie umów, a na naruszeniach nietykalności cielesnej skończywszy), lecz dochodzić ich musi przed odrębnymi ciałami - przed tzw. trybunałami administracyjnymi. Trybunały te nie są jednak - a przynajmniej nie były wtedy, zdaniem Diceya - sądami z prawdziwego zdarzenia, lecz organami administracyjnymi, złożonymi z samych urzędników, których decyzje ożywiane są duchem urzędniczym zupełnie innym od tego właściwego sędziom ${ }^{69}$. Najwyższą instancją w takim sądownictwie administracyjnym (sprowadzonym wciąż jeszcze do zasad postępowania administracyjnego) jest ciało równie administracyjne, a mianowicie Rada Stanu (Conseil d'Etat). Jednakże faktyczny charakter prawa administracyjnego zależy od urządzenia tzw. Trybunału Sporów Jurysdykcyjnych (Tribunal des Conflits), decydującego o tym, czy dana skarga dotyczy sprawy należącej do owej mglistej kategorii aktów rządowych, czy jest raczej właściwa sądom zwyczajnym. W czasie, w którym Dicey pisał $W_{\text {stęp }}$ do nauki o prawie konstytucyjnem, uznał ów Tribunal des Conflits za instytucję pośrednią częściowo administracyjną, częściowo sądową - a wiec wciąż niespełniającą stawianych przezeń wymogów praworządności ${ }^{70}$.

Dicey pisał na ten temat w okresie przejściowym. Zauważył znaczne przeobrażenia, jakie zaszły we Francji - szczególnie zniesienie, w wyjątkowo burzliwych okolicznościach, 19 września w 1870 r. art. 75 przepisu, który do tego czasu przetrwał wszystkie zmiany ustrojowe od końcówki XVIII stulecia ${ }^{71}$. Już w 1885 r. Dicey dostrzegal, że trybunały administracyjne $w$ ostatnich niemal czasach przybraty nawet charakter niby sądowy i przyjęty procedurę niby sadowa (po czym starał się zatrzeć to dobre wrażenie, wskazując na wyżej wymienione fakty). W przypisie z 1902 r. dodaje, że przeobrażenie to jest krokiem w stronę rozwiązań angielskich, zauważając przy okazji, że wciąż jeszcze żywe są wśród francuskich prawników nastroje przeciwne kompetencji w kwestiach administracyjnych trybunatów, majacych $w$ jakimkolwiek stopniu charakter sqdowy. Dla tychże bowiem, ilekroć wchodza w grę interesy państwa, administracya jako przedstawiciel państwa powinna byćjedynym sędziq we wtasnej sprawie $e^{72}$. Dla angielskiego prawnika-konstytucjonalisty taka uwaga - wskazująca na faktyczną tradycję i korzenie idei prawa administracyjnego - z miejsca dyskwalifikuje jakikolwiek system rządów $\mathrm{z}$ wszelkich pretensji do miana praworządnego. Zapewne kwestia ta przywodziła mu na myśl kazus doktora Bonhama z 1610 r., w którym sędzia Coke uznał za fundamentalną maksymę prawai zarazem podstawę legitymizacji systemu politycznego zasadę, że nikt nie może być sędzią we własnej sprawie ${ }^{73}$.

69 Jak zauważa Jaworski, catkiem innem jest myślenie urzędnika administracyjnego, a innem myślenie sędziego. Wskazuje także, że w takich przypadkach ujawnia siępewien esprit de corps (duch koleżeństwa), tendencja do ostaniania podwtadnych przez przetożonych (W.L. Jaworski, Nauka prawa administracyjnego..., s. 16).

70 A.V. Dicey, Wstęp..., s. 239-240.

71 Tamże, s. 243.

72 Tamże, s. 237.

73 Zob.: A. Bryk, Limits of Arbitrary Government..., s. 85-86. 


\section{Kwestia równości wobec prawa}

Oto uskutecznienie zasady niezależności egzekutywy od sądów. Zupełnie naturalna dla Anglika myśl, że wszelkie spory prawne rozstrzyga sąd, we Francji rozbija się o tak rozumianą doktrynę podziału władz, przez którą wielokrotnie odrzucano już tam propozycje ujednolicenia wymiaru sprawiedliwości. Wszystko wiedzie do daleko posuniętego immunitetu funkcjonariuszy francuskiej władzy publicznej ${ }^{74}$.

Zdaniem Diceya powodem, dla którego tak niepełne - nawet u progu XX w., kiedy pisał te słowa - były rządy prawa na Kontynencie (Jeśli weźmiemy Francyęza typpaństwa kontynentalnego), było właśnie to, że prawo administracyjne wyjmuje część obywateli tych pełniących urzędy państwowe - poza obręb powszechnego prawa. Poddaje ich prawu specjalnemu, stosowanemu przez takich jak oni urzędników. Tymczasem, choć w Anglii funkcjonariusze podlegają jurysdykcji specjalnej - trybunałom wojskowym czy kościelnym, a więc prawu, które może być nazwane administracyjnem - to nie podlegają jej wyłącznie; bowiem wszyscy obywatele Anglii podlegaja prawu krajowemu ${ }^{75}$.

Dicey, wychodząc od tak postawionej sprawy, pisze: $W$ Anglii wtadza korony i jej stug może niekiedy zmniejszać się lub zwiększać. Ale ta wtadza jakakolwiek ona jest, musi być wykonywana w zodzie z zwyczajnymi zasadami common la w, które reguluje stosunki między Anglikami. Inspektor fabryczny np. posiada szczególne prawa, które zostaty mu nadane aktem parlamentu; ale jeśli postuszny rozkazom swojego przetożonego w hierarchii, przekroczy wtadzę nadana mu przez prawo, staje się wówczas odpowiedzialny za szkody jakich byt powodem; nie może usprawiedliwiać się tem, że byt ściśle postuszny rozkazom urzędowym; a za straty jakich przyczynit, może odpowiadać przed zwyczajnymi sadami ${ }^{76}$.

W tym miejscu warto przytoczyć treść art. 5 Habeas Corpus (Amendment) Act z 1679 r.; ustawy, która miała poprawić, czy raczej usprawnić (stosowany już przeciw tyrańskim rządom i dla obrony praw obywatelskich), instrument writu habeas corpus - pisma, w którym sędzia żąda od funkcjonariusza korony (np. szeryfa), by stawił się przed jego obliczem i żeby miat [z sobą] ciato oskarżonego wraz z zarzutem, pod jakim został on pojmany.

Rzeczony artykuł z innego fragmentu pisma - Na twoja zgubę, w żadnej mierze $w$ tym nie zawiedź [Hereof in no way fail, at your peril] - czynił coś więcej niż tylko pustą groźbę; za uchylanie się od sędziowskiego rozkazu przewidywał konkretne sankcje: sto funtów grzywny za pierwsze tego rodzaju przewinienie oraz dwieście, wraz z pozbawieniem urzędu - za drugie. Po tym następuje fragment, którego wyróżnione części polecam uwadze: Wymienione grzywny uzyska więzień lub strona pokrzywdzona czy jej egzekutorzy (testamentu) lub zarzadcy (masy spadkowej) w drodze powództwa

74 Wade zauważal, że Dicey zaprezentował druzgocąca krytykę nieodpowiedzialności prawnej francuskich urzędników, lecz pominął wspomnieć o szeregu immunitetów, jakie angielskie prawo po dziś dzień przyznaje Koronie i departamentom (E.C.S. Wade, Appendix, [w:] A.V. Dicey, An Introduction..., s. 476).

75 A.V. Dicey, Wstęp..., s. 124, 229.

76 Tamże, s. 389-390. 
o zwrot dtugów, skargi, pisemnego zażalenia lub oskarżenia skierowanego przeciwko takim przestępcom, ich egzekutorom $i z a-$ rzqd com. I dalej... Roszczenia tego rodzaju dochodzone będa przed jakimkolwiek królewskim sądem $w$ Westminster, przy czym w postepowaniu nie dopuści się i nie zezwoli na postugiwanie się wykrętem, protekcja, przywilejem, dziataniem z rozkazu, wspótprzysiężnikami lub wstrzymywaniem procesu [...] czy wjeszcze inny sposób ${ }^{77}$. W duchu Diceyowskiej interpretacji widać wyraźnie, że sankcje zawarte w tym przepisie stanowią nie tylko karę dla samego nadużywającego władzy, ale i formę kompensaty dla poszkodowanego; owe sto i dwieście funtów, jakoby były ustawową wyceną krzywdy zwanej niestusznym zatrzymaniem.

To bardzo ścisłe rozumienie równości wobec prawa kategorycznie domaga się osobistej odpowiedzialności. Urzędnik w swoich działaniach podczas pełnienia funkcji nie może się skryć za urzędem, który reprezentuje. Każdy jego błąd sprawia, że zdany jest na łaskę prawa. Odpowiada on osobiście za wszystkie swoje przewinienia; a odpowiada warto nadmienić - własnym majątkiem.

Mieczysław Szerer przytacza szereg ciekawych przykładów tej doktryny, która z powodzeniem doczekała połowy XX w. Urzędowy almanach policji brytyjskiej z $1956 \mathrm{r}$. stwierdzał, co następuje: Każdy funkcjonariusz policji $w$ W. Brytanii jest niezawistym dzierżycielem urzędu publicznego. Jako konstabl wykonywa wtadzę udzielona sobie przez ustawe lub przez prawo zwyczajowe z tytutu swego urzędu i nie może jej wykonywać na czyjąkolwiek odpowiedzialność, lecz tylko na swoja wtasna. Toteż funkcjonariusz policji, wyjąszy przypadek dziatania w wykonaniu nakazu sędziowskiego, jest odpowiedzialny za wszelka swoja bezprawna lub btędnq dziatalność; bo nie jest stuga wtadzy policyjnej i, spetniając swe obowiązki, musi polegać na wtasnym uznaniu i wtasnej znajomości prawa $^{78}$.

Tak więc, choć w Anglii władza urzędnika może być większa lub mniejsza - to zawsze podlega on prawu na równi ze zwykłymi poddanymi Korony. We Francyi przeciwnie - gdzie po dziś dzień mówi się nawet, że jak strzela policjant, to znaczy, że strzela Republika - [...] jakkolwiek wtadza administracyi może być zmniejszona, jest zawsze rzecza pewna, że stosunkami prywatnych jednostek z panstwem rządza zasady odmienne od tych, jakimi poddane są stosunki pomiędzy obywatelami francuskimi $i^{79}$. Taki system jest uświęceniem zasady dwoistości prawa ${ }^{80}$, zmierzającym do poświęcenia dobra jednostki na ołtarzu interesu wspólnego.

W myśl zasady izonomii (idea druga) rządy prawa polegają na tym, że - jak ujął to Dicey (nie unikając podniosłego tonu): [...] nie tylko nikt u nas nie stoi ponad prawem, lecż̇e każdy cztowiek, jakikolwiek petnitby urząd, podlega prawom zwyczajnym królestwa

Habeas Corpus Act z 1679 roku, przeł. B. Lesiński, J. Walachowicz, [w:] Powszechna historia państwa i prawa. Wybór tekstów źródtowych, red. M.J. Ptak, M. Kinstler, Wrocław 1996, s. 307. Ortografia i interpunkcja zachowane z oryginału. Wyróżnienie własne.

78 M. Szerer, Sądownictwo angielskie, s. 70. Fragment ten zdaje się najzwięźlejszym z możliwych wyjaśnień tak dobrej renomy brytyjskiej policji.

79 A.V. Dicey, Wstęp..., s. 390.

80 M. Szerer, Sądownictwo angielskie, s. 44. 
i wyrokom sadów zwyczajnych. W Anglii idea równości przed prawem i ulegtości wszelkich klas spotecznych powszechnemu prawu, stosowanemu przez trybunaty zwyczajne, posunieta zostata do granic. U nas Anglików wszyscy funkcyonaryusze, począwszy od prezesa ministrów aż do konstablów i poborców podatku, ponosza taka samq odpowiedzialność, jak każdy inny obywatel za każdy czyn, nieusprawiedliwiony prawnie $e^{81}$.

Dicey ciągnie dalej: Akta sadowe petne sa spraw, w których funkcyonariusze zapozwani zostali przed sad $i$ ukarani lub skazani na grzywne za czyny, popetnione podczas wykonywania ich funkcyi, które jednak byty naduzyciem wtadzy, udzielonej przez prawo. Wszyscy urzędnicy, [...] nawet wówczas gdy wykonywają rozkazy swych przetożonych, ponosza odpowiedzialność za wszystkie czyny, do których ich ustawa nie upowaznia, zupetnie w ten sam sposób jak obywatel, niepetniacy żadnych funkcyi publicznych ${ }^{82}$.

\section{„Grzech pierworodny” prawa administracyjnego}

Oto panowanie prawa wytącza wszelka ideę uwolnienia urzędników lub innych funkcyonaryuszów od obowiąku postuszeństwa prawu, któremu podlega reszta obywateli, wyjęcia tychże z pod jurysdykcji trybunatów zwyczajnych, a więc wyłącza obowiązywanie prawa administracyjnego rozumianego na modłę francuską - prawa zakładającego, że [...] sprawy, w których interesowny jest rząd lub jego funkcyonaryusze, leża poza sfera jurysdykcyi trybunatów sadowych i rozpatrywane być musza przez ciata specyalne, ztożone w mniejszym lub większym zakresie z funkcyonaryuszów - dopuszczającego istnienie interesu innego niż ten wynikający ze zwyczajnej sprawiedliwości ${ }^{83}$.

Dicey zauważa, że prawo administracyjne urządzone jest wedle zupełnie innych zasad sprawiedliwości niż prawo powszechne stosowane w sporach między jednostkami; stawia ono państwo w pozycji uprzywilejowanej wobec obywatela, choćby w tym sensie, że przewinienia urzędu traktowane są z większą pobłażliwością, niż gdyby były dziełem osoby prywatnej. I tak jeśli państwo spowodowało u obywatela straty i zobligowane ma być do ich kompensaty, to strata owa nie będzie - jak w prawie cywilnym rozumiana jako nieodniesiony zysk, lecz jako faktycznie poniesiony koszt niedotrzymania przez państwo umowy ${ }^{84}$.

Niepraworządność tak rozumianego prawa administracyjnego nie bierze się z tego, że ma ono u swego źródła arbitralność. Nie jest bowiem do końca tak, jak rzecz widzą

81 Tamże, s. 123-124. Na potwierdzenie tej tezy warto przywołać historię z 1923 r., kiedy to na polecenie ówczesnego ministra spraw wewnętrznych, pod zarzutem agitacji wywrotowej, aresztowano i deportowano do ojczyzny kilku Irlandczyków. Jeden z nich zaskarżył ministra w sądzie i [...] okazato się, że z powodu bezprawności aresztowania i zsytki ciężkie następstwa pieniężne, jako odszkodowanie, grozity nie tylko ministrowi, ale także wszystkim, którzy przyczyniając się do wykonania tego zarządzenia pomagali tamać prawo; grozity m. i. także zatodze statku, który odwozit deportowanych. Trzeba byto uciec się do procedury tzw. Indemnity Act, to jest szczególnej ustawy, która zalegalizowata dziatanie wtadz w danym przypadku [...] ale za razem przyznata pokrzywdzonym specjalne odszkodowanie z funduszów państwowych (tamże, s. 45, przyp.).

A.V. Dicey, Wstęp..., s. 124.

83 Tamże, s. 131.

84 Tamże, s. 233-234. 
niektórzy angielscy prawnicy, którzy odmawiają mu znamion prawa, jako że służy ono poprostu do określania maksym, kierujacych egzekutywa przy spetnianiu jej wtadzy, jeśli niearbitralnej, to w kazdym razie dyskrecjonalnej. Prawnicy ci nie dostrzegają bowiem, że $w$ ciagu XIX wieku droga godnej uwagi metody prawodawstwa sadowego arbitralne korzystanie z przywileju przeistoczyto się do pewnego stopnia w system prawa określonego ${ }^{85}$. Tym sposobem Diceyowa wątpliwość co do prawa administracyjnego jest bardziej subtelna niż prosty zarzut arbitralności i nie-prawności, a bierze się - w pewnym zakresie przynajmniej, jak można przypuszczać - z koniunkcji leseferystycznej i pozytywistycznej perspektywy postrzegania prawa.

Patrząc przez ten pryzmat, za niepraworządność prawa administracyjnego odpowiada pewien jego doktrynalny grzech pierworodny; aksjologia stojąca u jego źródeł, jeszcze w czasach zamierzchłych - przed Wielką Rewolucją Francuską. W swej istocie, a właściwie z pochodzenia, prawo administracyjne przeznaczone jest (i jest takim po dziś dzień) do ochrony interesów państwa czy też interesu publicznego lub wspólnego $^{86}$ (obecnie także stusznego interesu obywatela), właśnie w konfrontacji z zasadami reszty systemu prawa - które to w szczególnych przypadkach owe interesy mogłoby podważać. W tym względzie pierwotna arbitralność i dyskrecjonalność działań administracji i samego jej prawa - realizacji owej zasady rozdziatu wtadz - była jedynie wtórna wobec celu ich istnienia, podminowywania systemu skierowanego (w tym ujęciu) wyłącznie na ochronę interesu indywidualnego. W tym miejscu warto zacytować za Tocqueville'em anonimowego intendenta francuskiego doby dawnego ustroju. Tak oto argumentuje on za interwencją - tzw. ewokacją - Rady Królewskiej w sprawy, które byłyby przedmiotem zainteresowania administracji: Sądy ogólne podlegaja statym prawidtom, które obowiązuja je do sttumienia czynów sprzecznych z prawem; lecz rada może pogwatcić prawo dla celu użytecznego ${ }^{87}$.

Wygląda na to, że w oczach Diceya (przynajmniej w pierwszym wydaniu) taka teleologiczna orientacja prawa administracyjnego jest niepraworzadna po prostu dlatego, że z konieczności wiedzie wprost do arbitralności, gdyż skłania trybunały administracyjne do sięgania po wartości spoza systemu prawnego. Prowadzi to w efekcie do stosowania wobec oskarżonego raczej kryterium posłuszeństwa (w dobrej wierze) przełożonym (czy raczej wydanym przez nich aktom pod-ustawowym) - właściwie więc kryterium słusznej intencji - nie zaś szkody skarżącego ani nie posłuszeństwa ustawom ${ }^{88}$. Można przypuszczać jednak, że oprócz tych praktycznych względów znaczenie ma dla Diceya także i sam fakt teleologiczności prawa administracyjnego, jako samej w sobie rażącej dla teorii pozytywistycznej - oczekującej od prawa ściśle tetycznego charakteru, więc i ograniczenia się do swojej dziedziny. Wzgląd ten popycha Diceya do tego, by wręcz podważyć sam prawny charakter (w angielskim rozumieniu) prawa administracyjnego ${ }^{89}$.

\footnotetext{
85 Tamże, s. 392-395.

86 W polskim prawie administracyjnym pojęcia te są nieoznaczone.

87 A. Tocqueville, Dawne rzady..., s. 56.

88 A.V. Dicey, Wstęp..., s. 241.

89 Zob.: tamże, s. 400.
} 


\section{Kwestia słuszności}

Pod władzą praw nawet posłuszeństwo bona fide rozkazom przełożonych nie jest dostatecznym usprawiedliwieniem. Wedle takiego prawa agenci cywilni korony to tylko jednostki optacane po to, by pracowaty na rachunek rzadu; nie stanowia oni nic podobnego do tego, co cudzoziemcy nazywaja "hierarchiq oficyalna”. Dicey wbrew przypisywanej mu jednoznacznej gloryfikacji takiego rozwiązania wykazuje jednak i jego wady.

Już samo położenie angielskiego urzędnika państwowego jest wyjątkowo trudne; musi na każdym kroku mieć baczność na wszelkie szczegóły formalne w grze, w której stawką jest jego dobytek, a nagrodą nie jest nawet szacunek społeczny. Gdy wreszcie taki urzędnik, dajmy na to, przedstawiciel Ministerstwa Handlu - według Merchand Shipping Act z 1876 r. mający za zadanie zatrzymania w porcie każdego statku, którego stan techniczny zagraża życiu i zdrowiu załogi i pasażerów - trafia wreszcie przed sąd ze skargi armatora, to sędziowie przysięgli zwykle więcej maja wspótczucia dla poszkodowanego wtaściciela okrętu, niż uznania dla gorliwości urzędnika, starającego się wypetnić swój obowiazek i zapobiedz niebezpieczeństwu, grożacemu ludziom.

Kolejnym problemem jest egzekwowanie podległości służbowej. Zdarza się częstokroć, że uchodza bezkarnie ciężkie wykroczenia przeciw obowiązkom, popetniane przez funkcyonaryuszów - takich jak choćby kazus pewnego urzędnika MSZ-u, który ujawnił prasie treść ważnej korespondencji dyplomatycznej, a nie poniósł żadnej odpowiedzialności. Wszystko to paraliżuje egzekucję ustaw, szczególnie gdy sędziowie przysięgli i trybunaty sprzymierzyli się przeciw rzadowi [...], który troszcząc się [...] jedynie o porzadek publiczny, postawiony jest w fatszywem potożeniu obrońcy, który występuje we wtasnym interesie - mimo że z założenia realizuje (wyznaczony przez parlament) interes wspólny.

W tym miejscu Dicey wyjaśnia, na przekór opinii, jaka do niego przylgnęła, że jego zamiarem nie było potępienie tak rozumianej idei prawa administracyjnego - a cóż może być bardziej niepochlebnego dla instytucji społecznej jak stwierdzenie, że jest ona sprzeczna z praworządnością. Tutaj Dicey wykazuje się typowo pozytywistycznym analityzmem, pokazując że jego celem było jedynie ukazać definicyjną sprzeczności prawa administracyjnego z angielską ideą rządów prawa. Wyraźnie daje do zrozumienia, że zupełnie odrębną jest kwestia stuszności takich rozwiązań ${ }^{90}$.

Dodatkowo interpretacji opinii Diceya o sprzeczności idei prawa administracyjnego z brytyjską konstytucją powinno się dokonywać właśnie w kontekście jego uwag na temat tego, co należy rozumieć przez prawo "niekonstytucyjne” - tego, że konsekwencją indukcyjności konstytucji jest jej nienormatywny charakter (patrz: 3d).

90 Tamże, s. 247-249. 


\section{ŚCIEŻKI EWOLUCJI RZĄDÓW PRAWA I PRAWA ADMINISTRACYJNEGO}

Godne odnotowania wydają się wywody Diceya dotyczące ewolucji systemu prawa administracyjnego - właściwie pewne studia porównawcze, $w$ których zestawia ten system prawa z niektórymi rozwiązaniami angielskimi. Wskazuje na analogie prawa administracyjnego do common law, jako że oba te systemy mają charakter tego, co w Anglii zwie się case law; prawa tworzonego przez sędziów, prawa indukowanego z orzeczeń: nieskodyfikowanego i skutecznie opierającego się kodyfikacji - w obu przypadkach przez wzgląd na zachowanie autorytetu sędziów i w wyniku roli doktryny i autorytetów.

Dicey wymienia też pewne podobieństwa droit administratif do (nomen omen) angielskiego equity law (prawa stuszności), prawa kierującego się wymogami stuszności, przeciw zachowawczości prawa powszechnego. Equity law otrzymywało sankcję Lorda Kanclerza i pierwotnie stanowiło odrębny od common law dział prawa ${ }^{91}$. Warto nadmienić, że było to prawo stosowane, na zasadzie bezpośredniej ingerencji Lorda Kanclerza, w osobnych sądach (zwanych kanclerskimi), które szereg wieków temu w proteście przeciw sztywnej zachowawczości prawa zwyczajowego - zaczęty wcielać w życie wymogi „stuszności” [...] i modernizować w ten sposób wymiar prawa [...] Nierzadko $z$ darzato się, że dwie te kategorie sadów [common law i equity law] popadaty w konflikt ze soba i taka sama sprawę rozstrzygaty najzupetniej sprzecznie, z czasem jednak pierwotna przeciwstawność ustępowata miejsca uzupetnianiu się ${ }^{92}$.

Wychodząc od zagadnienia orientacji prawa administracyjnego na interesie publicznym, Dicey szkicuje krótki rys historii droit administratif. W następstwie Wielkiej Rewolucji władza wykonawcza we Francji osiągnęła pełnię niezależności, co było tylko zwieńczeniem trendu żywego jeszcze w czasach l'ancien régime. Władze publiczne nie tylko same rozstrzygały kwestie administracyjne, ale i decydowały, co kwalifikuje się do tej kategorii spraw. W rzeczy samej wszystko byto arbitralne; nie byto żadnego istotnego prawa administracyjnego. Wedle powszechnej opinii prawo to zrodziło się wraz z Konstytucją Konsularną z grudnia 1799 r., gdy pojawiło się - najzupełniej zależne od woli głowy państwa - sądownictwo administracyjne w wykonaniu członków Rady Stanu i gdy usankcjonowano rozdziat wtadz mocą wspomnianego art. 75.

Z czasem, na przestrzeni całego XIX w., narastać zaczęło orzecznictwo sądów administracyjnych, wypracowały się ogólne zasady tej gałęzi prawa, a funkcje sądowe Rady Stanu wyodrębniły się od jej czynności administracyjnych. Ciągłość tego rozwoju tylko $\mathrm{w}$ nieznacznej mierze zachwiana była przez przewroty polityczne. $\mathrm{Z}$ pozoru rewolucyjne zniesienie art. 75 w 1870 r. niewiele zmieniło, gdyż urzędniczy immunitet przetrwał w art. 114 Kodeksu karnego. Wraz z prawodawstwem z 1872 r. trybunały administracyjne uzyskały określoną formę, a ich orzeczenia nabierały charakteru wyroków z prawdziwego zdarzenia i stały się najzupełniej wiążącymi dla administracji. Wciąż

91 Tamże, s. 388, 401.

92 M. Szerer, Sądownictwo angielskie, s. 35-37. 
w znacznej mierze to egzekutywa decydowała, jaka sprawa przynależy do sadownictwa administracyjnego, a jaka nie - lecz wyklarować się już zdołał system prawa.

Punktem najbardziej uderzajacym $w$ historii prawa administracyjnego francuskiego jest to, że zurzadzeń stworzonych dla faworyzowania czynów prerogatywy arbitralnej wyszedt system praw uznanych i procedury sadowej, bardzo zbliżony do przyjętych form prawa. [...] autorytet arbitralnej egzekutywy taki, jaki istniat w r. 1800, już przestat istnieć dla tych spraw, które objęte sa kompetencya trybunatów administracyjnych. Prawo administracyjne, jakkolwiek stosowane przez ciata, które, ściśle mówiąc, nie sa sądami, i chociaż samo prawem, $w$ tem znaczeniu, jak Anglicy temu wyrazowi nadaja, nazwane być nie może, zbliża się bardzo do prawa; różni się ono zupetnie od zasad wtadzy arbitralnej ${ }^{j 3}$. W tym miejscu możemy dostrzec ścieżkę, na którejpuissance publique (władza publiczna) zastąpiona zostaje service publique (służbą publiczną), przez której cel (interes publiczny) definiuje się francuskie prawo administracyjne ${ }^{94}$.

Dicey, zestawiając common law $\mathrm{z}$ droit adminstratif, wskazuje na jeszcze jedną ważną analogię. Zdaje się dotykać tym sposobem sedna co najmniej jednego z głównych wątków ewolucji polityczno-prawnej zachodniego modelu ustrojowego. Rozwój obu $\mathrm{z}$ tych systemów, tak rzekomo różnych, ujawnia zdumiewające podobieństwo - demaskując ewolucję jako konwergencję: historię wydzielania się niezależnego sądownictwa z władzy wykonawczej. Kiedy z Rady Stanu, która przejęła funkcje wykonawcze i sądowe, „wypączkowały” te ostatnie pod postacią komitetów sądowych i kiedy komitety te, początkowo mające jedynie doradczy charakter, zaczęły wiązać swoimi decyzjami, to studentowi prawa angielskiego - poucza Dicey - przypomnieć się powinna historia zwieńczona powstaniem Komitetu Sądowego Rady Prywatnej (The Judical Commitee of Pricy Council).

Historia ta wyjaśnia jak, sposobem catkiem naturalnym [...], acz wspomaganym prawodawstwem, [...] czynności sadowe Rady zostaty oddzielone od wtadzy wykonawczej i jak ten rozdziat dat początek trybunatom, których przyczepienie do egzekutywy politycznej byto czysto historyczne. Także analogiczna forma wyroków zarówno Rady Stanu (która we Francji zniesiono w 1872) i Rady Prywatnej (a która w Anglii dziś jest już tylko prostym przeżytkiem) - przedstawiajacych sie jako [używając angielskiej terminologii] rady pokornie udzielane koronie - odsyta nas do tego dawniejszego okresu konstytucyjnych dziejów Anglii, kiedy interwencja Rady, t.j. egzekutywy, w czynnościach sądowych byta prawdziwa groźbą dla panowania prawa, będącego rękojmią wolności angielskiej ${ }^{95}$.

93 A.V. Dicey, Wstęp..., s. 395-400.

94 Por.: J.Zimmermann, Prawo administracyjne, s. 33. Uwagi Diceya na temat ewolucji droit administratif warto skonfrontować ze spostrzeżeniami Jaworskiego na temat francuskiego sądownictwa administracyjnego (W.L. Jaworski, Nauka prawa administracyjnego..., s. 42-52).

95 A.V. Dicey, Wstęp..., s. 401-410. Wade wskazuje, że Diceyowska interpretacja prawdziwej roli Conseil d'Etat była historycznie poprawna do 1848 r. (szczególnie gdy idzie o paralelę do Komitetu Sądowego Rady Prywatnej) - lecz nietrafna, gdy idzie o stan rzeczy z końca XIX w. Wynika to z dostrzeżenia przez teoretyków francuskich po 1848 r. nietożsamości pojęć prawa administracyjnego i sądownictwa administracyjnego (E.C.S. Wade, Appendix, [w:] A.V. Dicey, An Introduction..., s. 476). 
Dopiero w kontekście tego zestawienia - zawartego w Dodatku do wydania z 1902 r. - można uchwycić znaczenie uwagi Diceya (z pierwszej edycji) o tym, jak niewiele brakowało, by i w Anglii rozwinęłyby się instytucje odpowiadające francuskiemu systemowi prawa administracyjnego. Za Tudorów i Stuartów Anglia była na drodze do rozwinięcia się w niej takiego właśnie rozdziału władz, jaki zrealizował się po drugiej stronie kanału La Manche. Dicey porównuje Conseil d'Etat do Sądu Izby Gwiaździstej - intensywnie wykorzystanego przez monarchów w dobie absolutyzmu w Anglii.

Coś na kształt prawa administracyjnego w wersji Diceyowskiej - z wyjęciem spod prawa spraw dotyczących interesu publicznego, jak i samych agentów królewskich w Anglii powstałoby, gdyby to pogląd Francisa Bacona na rolę sędziów jako lwów przy tronie wszechmocnego suwerena ${ }^{96}$ zwyciężył nad przekonaniami Edwarda Coke'a, widzącego trybunały raczej w roli stróżów supremacji prawa i zrównoważonego ustroju. Właściwie należy powiedzieć, że jego zalążki przetrwałyby i wyklarowałyby się w droit administratif, gdyby losy Anglii potoczyły się nieco inaczej. Wziąć wystarczy pod rozwagę angielski system writów - pism sądowych, które formalnie wydawane są w imieniu Korony. Jak Bacon pisał do króla: Writ jest środkiem przy pomocy którego dawne prawo angielskie usuwato z pod kompetencji trybunatów zwyczajnych wszystkie sprawy, gdzie w gre wchodzity, interes lub wtadza jego Królewskiej Mości, celem oddania ich pod sąd kanclerza Anglii. Jego Królewska Mość wie o tem, że kanclerz królewski jest zawsze gtównym doradcą i stuga monarchii pod bezpośrednim kierownictwem króla; jest on więc skutkiem tego stróżem pewnym i czujnym praw królewskich ${ }^{97}$.

96 W swoim eseju O wymiarze sprawiedliwości Bacon pisał: Niechaj [...] pamiętaja sędziowie, że tron Salomona z obu stron podtrzymywaty lwy; niechaj wtaśnie sędziowie będa tymi lwami, lecz lwami, które się znajduja pod tronem $w$ tym znaczeniu, iżby dawali baczenie, by nie uczynić jakiejś ujmy czy też przeciwstawić sięjakimś uprawnieniom suwerennym. Wymowę tego słynnego fragmentu lagodzi ciąg dalszy: A jednocześnie niechaj sędziowie nie pozostają tak dalece w niewiedzy co do swoich wtasnych uprawnień, iżby myśleli, że nie jest im pozostawione, jako gtówna cześć ich zadania, madre stosowanie praw. Jeszcze większe znaczenie wydają się mieć wcześniejsze fragmenty. Bacon już na samym początku stwierdza jasno, że sędziowie winni pamiętać, że ich zadaniem jest jus dicere, nie zaś jus dare: interpretować prawo, nie zaś je tworzyć czy dawać, i że niedopuszczalne jest dla sędziego uzurpować sobie władzę, jaką przypisuje sobie Kościót rzymski, który pod pretekstem, że wyktada Pismo, nie waha sie je uzupetniać, zmieniać i gtosić to, czego w nim nie znajduje, tudzież wprowadzać rzeczy nowe pod pozorem dawności. W kontekście zestawienia formalno-pozytywistycznych, tetycznych rządów prawa i ukierunkowanego na dobro wspólne prawa administracyjnego wymowna jest opinia Bacona, że sędziowie winni ponad wszystko pamiętać końcowe stowa rzymskich Dwunastu Tablic: salus populi suprema lex; i powinni wiedzieć, że prawa sa rzecza zdradliwa i wyrocznia źle natchniona, jeśli nie mają na widoku tego wtaśnie celu. Toteż uktadają się szczęśliwie sprawy państwowe tam, gdzie wtadca i państwo często naradzaja się z sędziami; i gdzie z drugiej strony sędziowie często naradzają się z królem $i$ państwem w sprawach, w których w grę wchodzi interes państwa. Sprawa o znaczeniu państwowym nazywam nie tylko to, co dotyczy uprawnień wtadzy najwyższej, lecz również wszystko, co wprowadza jaką́ doniosta zmianę lub niebezpieczny precedens lub też dotyczy wyránnie znacznej części ludności. I niechaj nikt sobie nie wyobraża, że sprawiedliwe prawa i trafna polityka to rzeczy jakoś ze soba niezgodne; sa one bowiem podobne do tchnień żywotnych i ściegien z których pierwsze wprawiaja w ruch drugie (F. Bacon, Eseje, przeł. Cz. Znamierowski, Warszawa 1959, s. 237-243, Biblioteka Klasyków Filozofii).

97 S.R. Gardiner, History of England, s. 7, cyt. za: A.V. Dicey, Wstęp..., s. 252. 
I oto system ten - podkreślmy to jeszcze raz - będący narzędziem ewokacji i gwarantem królewskich prerogatyw, został odwrócony, by jego ostrze skierować przeciwko monarszemu absolutyzmowi. Sam los writu Habeas Corpus najlepiej ilustruje ten paradoks ${ }^{98}$.

Dicey wieńczy swoje rozważania o prawie administracyjnym i rule of law w pierwszym wydaniu stwierdzeniem (poniekąd wbrew swoim wcześniejszym uwagom, dystansującym się od idei prowolnościowej preformacji ustroju Anglii) ${ }^{99}$, że starania Stuartów, by zaprowadzić w Anglii absolutyzm, nie powiodty się przede wszystkim dlatego, iż system prawa administracyjnego w ogóle jest catkowicie przeciwny zwyczajom równości w obec prawa, które od dawna byty cecha zasadnicza instytucyji angielskich ${ }^{100}$.

Autor wskazuje na zasadniczą tożsamość polityczną protestów francuskich liberałów przeciw prawu administracyjnemu i Radzie Stanu w 1830 r. oraz opozycji purytanów i wigów przeciw jurysdykcji Rady Prywatnej, Izby Gwiaździstej czy nawet przeciw sądowi kanclerskiemu w XVI i XVII w. Wobu krajach grozito poważne niebezpieczeństwo, że przywilej zapanuje nad prawem. W tym miejscu autor wskazuje też na funkcjonalne podobieństwo między rewolucjami 1688 r. w Anglii i 1830 r. we Francji. Zdaniem Diceya ich rezultat, choć na pierwszy rzut oka odmienny, okazał się zbieżny. O ile Anglicy, znosząc arbitralność Izby Gwiaździstej i Rady, nie znieśli sądów kanclerskich i pozwolili trwać equity law (jako instytucji prawie równie użytecznej jak droit administratif), które z czasem zatraciło odrębność w systemie sądownictwa; o tyle Francuzi okazali się względem instytucji bardziej zachowawczy, lecz również poszli tropem redukcji arbitralności prawa administracyjnego ${ }^{101}$.

98 Jak pisał Edward Jenks: W rzeczy samej, niemato jest do wyjaśnienia, gdy idzie o Habeas Corpus. Po pierwsze wydaje się dziwnym (czy raczej wydawatoby się dziwnym w każdym innym niż nasz systemie prawnym), że królewski writ, ten „wysoki writ prerogatywy”, jak określa go Blackstone, miatby być wspaniatym narzędziem do zwalczania wtasnych rozkazów króla. [...] Jest być może najbardziej żenujacym odkrycie - a im więcej ktoś dowiaduje się o dawnych writach Habeas Corpus [...] tym bardziej się w tym utwierdza - że niezależnie od tego jakie mogto być jego ostateczne zastosowanie, writ Habeas Corpus byt pierwotnie przeznaczony nie do tego, żeby wyciagać ludzi z więzienia, lecz by ich do niego wsa$d z$ ac (E. Jenks, The Story of Habeas Corpus, [w:] Select Essays in Anglo-American Legal History, t. 2, Boston 1908, s. 531-548). Wyróżnienie w oryginale. Przekład własny z: In truth there is not a little about the Habeas Corpus which requires explanation. In the first place it seems odd (or it would seem odd in any system of law but our own) that the king's writ, this 'bigh prerogative writ,' as Blackstone calls it, should have been the great engine for defeating the king's own orders. [...] This perhaps is the most embarrassing discovery, the more one studies the ancient writs of Habeas Corpus (for there were many varieties of the article) the more clear grows the conviction, that, whatever may have been its ultimate use, the writ Habeas Corpus was originally intended not to get people out of prison, but to put them in it.

99 Jak już wspominano, Dicey uznawał za złudzenie myśl, jakoby wspótczesna wolność konstytucyjna byta owocem postępu wstecznego, t.j. powrotu do mądrości naszych przodków barbarzyńskich (A.V. Dicey, Wstep..., s. XIV).

100 Tamże, s. 253.

101 Tamże, s. 405-406. Patrząc z dzisiejszej perspektywy, można by raczej zestawić, jako rewolucyjne, znamienne ustawy z lat 1679 i 1872. Angielski Habeas Corpus Amendment Act i francuska ustawa z 1872 r., przywracająca Radę Stanu, ale już jako sąd administracyjny - obie zwieńczyły proces przemian, który od jakiegoś już czasu domagał się usankcjonowania. W tym sensie, choć rozbieżność formy jest wyraźna, efekt bardzo podobny - ugruntowanie (szerzej pojmowanej) praworządności. 
Francuskie prawo administracyjne, szczególnie zaś jego wyodrębnione sadownictwo, powstało za sprawą generalnego wyodrębnienia i dyskrecjonalności władzy wykonawczej, wedle mylnego pojęcia podziatu wtadz; wychodząc od tego grzechu pierworodnego, prowadzącego logicznie do domniemanej zupełnej nieodpowiedzialności rządzących. Francuzi więc poszli zupełnie inną niż Anglicy drogą. Nie tak jak oni, znosząc suwerenność egzekutywy i zmierzając ku ujednoliconemu systemowi prawa - lecz metodą drobnych ustępstw, bez naruszenia owej zasady podziatu wtadzy. Wprowadzili praworządność w postaci pewnych rozwiązań, które w ostateczności zawiodą do współczesnego postępowania sądowo-administracyjnego ${ }^{102}$.

Pod wptywem prawników raczej, niż mężów politycznych, prawo administracyjne [...] jest $w$ trakcie pozbywania się $w$ znacznej części swego charakteru arbitralnego i w ciqgu ostatniej potowy XIX wieku przeistoczyto sie w system prawa mniej więcej określonego, wykorzystywanego przez ciata, którym brak istotnie pewnych zalet, jak np. niezależności zupetnej od wtadzy wykonawczej, która wedtug Anglików powinna przystugiwać wszystkim trybunatom, ale które jednakże nie sa tylko wytacznie narzędziem egzekutywy rzadowe ${ }^{103}$.

Ostatecznie więc, z dzisiejszej perspektywy, choć Anglicy i Francuzi drogi obrali inne, zmierzali w praktyce $\mathrm{w}$ to samo miejsce - ku kontroli poczynań urzędników. Prawo administracyjne, czy raczej sądownictwo administracyjne, jest owocem ewolucji i narastania rozwiązań i dzierży z sobą ów grzech pierworodny, z którego wyrosło i bez którego uświadomienia nie może być w pełni zrozumiane.

\section{PODSUMOWANIE}

Mieczysław Szerer w 1959 r., pisząc o sadownictwie Anglii, zauważał, jak wielką popularnością na Wyspach i na Kontynencie cieszyła się Diceyowska teoria, że ustrojowi brytyjskiemu nie znane jest prawo administracyjne i że w Anglii zamiast tego panują rządy prawa. Komu znana jest ta teoria - od lat gtoszona w dzietach konstytucjonalistów brytyjskich - ten nie bez zdziwienia stwierdzi, że trwa na przekór jawnie widocznej rzeczywistości. Szerer wylicza szereg trybunałów specjalnych pod bezpośrednim nadzorem ministerialnym, obsadzonych specjalistami w danej dziedzinie, nie zaś prawnikami. Rozrost sądownictwa administracyjnego był w jego oczach konsekwencja stopniowego odwracania się Anglików od prawowiernego laisser-faire'yzmu w polityce zarówno ekonomicznej, jak spotecznej, a wynikał ze wzrostu znaczenia interesu społecznego - wybicia się go ponad tradycyjne zasady swobodnej gry konkurencyjnych egoizmów ${ }^{104}$.

102 Tamże, s. 379. Wade w tym kontekście wskazuje, że brak osobnego systemu sądownictwa administracyjnego w Zjednoczonym Królestwie nie jest wynikiem jakiegoś szczególnego przywiązania Anglików do idei rządów prawa, ale raczej idiosynkratyczną pozostałością po siedemnastowiecznej walce Parlamentu z monarchami (E.C.S. Wade, Appendix, [w:] A.V. Dicey, An Introduction..., s. 477).

103 A.V. Dicey, Wstęp..., s. 408.

104 M. Szerer, Sądownictwo angielskie, s. 45. Wyróżnienie w oryginale. 
Diceyowski Wstęp do nauki prawa konstytucyjnego uznaje się czasami za wiktoriańską biblię wolnego handlu. W oksfordzkim słowniku politologicznym zaraz po definicji prawa administracyjnego wymienia się Wstęp do nauki o prawie konstytucyjnem jako wyraz oporu samego A.V. Diceya, aby zaakceptować ideę, zgodnie z która szczegótowe $i$ konkretne zasady prawne określaja podejmowanie decyzji administracyjnych, i podkreśla, że pomimo tego oporu angielskie prawo rozwinęto prawo administracyjne, zwtaszcza po $1960^{105}$. Proces ten dokonywał się już w czasach Diceya, co zostało przez niego odnotowane. W wydaniu Wstępu... z 1902 r. pojawia się zastrzeżenie, że najnowsze prawodawstwo w szczególnych razach nadaje urzędnikom pewnego rodzaju wtadzę sadowa, jednakże świadectwo praktyki dowodzi, że sądownictwo powszechne zachowuje kompetencję rozstrzygania skarg na decyzje trybunałów administracyjnych (w drodze writ of certiorari wydawanego przez King's Bench) ${ }^{106}$; przekonuje o tym, że owe istniejace [...] innowacje zostaty wywotane względami użyteczności publicznej i nie świadcza bynajmniej, żeby angielscy mężowie stanu zamierzali zmienić zasadnicze podstawy prawa angielskiego. Pozwalało to Diceyowi podtrzymywać tezę przewodnią, że [w] Anglii nie istnieje rzeczywiste prawo administracyjne, a nawet że owe główne cechy prawa administracyjnego - zasady uprzywilejowujące państwo jako stronę w sporze z obywatelem i niekompetencją sadów powszechnych - uniemożliwiają asymilacje prawa administracyjnego z jakimkolwiek dziatem prawa angielskiego ${ }^{107}$.

W tym miejscu podnieść wypada więc i kwestię trafności przyjętych przez Diceya rozstrzygnięć definicyjnych. Jak wskazuje Wade, w przyjętym przez niego postrzeganiu droit administratif tkwi podwójny błąd. Istnienie systemu prawa administracyjnego, tak jak jest ono rozumiane we Francji, nie jest uzależnione od istnienia systemu specjalnych trybunałów wykonujących sądową kontrolę nad urzędnikami w ich relacjach z osobami prywatnymi, a już na pewno $\mathrm{n}$ i e jest uzależnione od wyjęcia funkcjonariuszy administracji spod odpowiedzialności prawnej ${ }^{108}$. $Z$ tej perspektywy wizja Diceya jest, rzec by można, karykaturalna: wyolbrzymia bowiem cechy specyficzne różnych tradycji prawnych - cechy czasem będące ledwie reliktami ewolucji politycznej i czyniąc z nich istotę tychże tradycji, orzeka stanowczo o ich nieprzystawalności.

Nie poprzestając na objaśnianiu koncepcji Diceya przez klucz ideologiczno-polityczny, można jednak jego teorię wziąć za dobrą monetę, a wtedy wyraźniejszy będzie jej kontekst prawno-doktrynalny. Koncepcję wolnych od prawa administracyjnego rząów prawa da się przypisać nie tylko duchowi brytyjskiego wiktoriańskiego kapitalizmu przemysłowego i próbie obrony indywidualistycznej tradycji common law przed kolektywizmem. Jest ona także - a raczej przede wszystkim - rezultatem spe-

105 Stownik politologii, s. 457.

106 Tamże, s. 47-48. Droga ta jest współcześnie bazą dla świeżej na gruncie angielskim praktyki judical review (podobnie jak w Stanach Zjednoczonych jest podstawą judical review od pamiętnej sprawy Marbury versus Madison z 1803 r.), choć jedynie w obrębie prawa administracyjnego. Sprawami tego typu zajmuje się tzw. Sąd Administracyjny (Administrative Court), który jednak nie jest odrębnym typem trybunału, lecz specjalistycznym panelem Sądu Ławy Królewskiej.

107 A.V. Dicey, Wstęp..., s. 390-392.

108 E.C.S. Wade, Appendix, [w:] A.V. Dicey, An Introduction..., s. 476. 
cyficznych dla pozytywizmu prawniczego rozstrzygnięć definicyjnych. Widać w niej doktrynę formalnej praworządności, zogniskowaną na interesie wolnej od społecznych więzi i zobowiązań jednostki; z wyraźnym akcentem kładzionym na proceduralne gwarancje praworządności (A5); koncepcję zakładającą wyalienowanie zobiektywizowanego prawa od społeczeństwa za sprawą mechanizmu parlamentu - proceduralnego suwerena (a więc i zawierającą elementy formalno-pozytywistycznie ujmowanego państwa prawa, jako państwa zwierzchniego wobec społeczeństwa).

W tym również sensie doktryna ta nie wykracza poza typowo dziewiętnastowieczne formalno-pozytywistyczne ujmowanie idei prawa, postrzegając je wyraźnie tetycznie, jako rozkaz suwerena. Właśnie owo tetyczne ujecie, a w rezultacie przypisywanie tetyczności także angielskim rządom prawa, wyklucza ex definitione uznanie na jego gruncie prawa administracyjnego, jako zorientowanego teleologicznie (tym samym z zasady skłonnego do arbitralności, ponieważ sięgającego poza system prawa).

Jednocześnie jednak Dicey nie „zabraniał” tego typu wykraczania poza to, co identyfikował jako prawo. Dostrzegał inne niż praworządność wartości, takie jak właśnie stuszność, interes publiczny, moralność polityczna itd. Tyle tylko, że owe wartości lokował - pozytywistyczną manierą - na zewnątrz systemu prawnego, więc i poza ideą rządów prawa. Prawo administracyjne - sięgające po takie pozaprawne wartości, czyli nieprzystające do wąsko rozumianych rządów prawa - wbrew pozorom n i e stanowiło w jego systemie teoretycznym czegoś nielegalnego, godnego potępienia ani nawet nieważnego, a jedynie odstępstwo od uogólnionej praktyki ustrojowej. Inną sprawą jest trafność osądu Diceya na temat tego, jaka owa praktyka rzeczywiście była.

Pozostaje więc koncepcja, która jest świadectwem swoich czasów i jako taka może być jednym z istotnych kluczy interpretacyjnych ewolucji państwa i prawa w zachodniej historii politycznej. Ale zawierać ona może także i pewne elementy inspirujące $\mathrm{z}$ aktualnej perspektywy. Jej praktycznym rezultatem jest bowiem silny akcent położony na osobistą odpowiedzialność urzędnika za jego poczynania niezgodne z prawem. Pewien renesans tego typu podejścia dostrzec można choćby w różnych odmianach tzw. nowego zarzadzania publicznego (new public management). Jednym z ciekawszych polskich przykładów dążności w tym kierunku może być Ustawa z dnia 20 stycznia 2011 r. o odpowiedzialności majątkowej funkcjonariuszy publicznych za rażące naruszenie prawa ${ }^{109}$. Choćby z tego powodu trudno oryginalną koncepcję wiktoriańskiego konstytucjonalisty całkiem odstawić do lamusa.

\section{BIBLIOGRAFIA}

Allan T.R.S., Dworkin and Dicey. The rule of law as integrity, „Oxford Journal of Legal Studies” 1988, t. 8, nr 2, [online] http://dx.doi.org/10.1093/ojls/8.2.266.

Arendt H., Korzenie totalitaryzmu, t. 1, przeł. M. Szawiel, D. Grinberg, Warszawa 1993, Krytyka.

109 Ustawa $z$ dnia 20 stycznia 2011 roku o odpowiedzialności majątkowej funkcjonariuszy publicznych za rażace naruszenie prawa, Dz. U. 2011, nr 34, poz. 173. 
Arystoteles, Polityka, przel. L. Piotrowicz, Warszawa 2006.

Bacon F., Eseje, przeł. Cz. Znamierowski, Warszawa 1959, Biblioteka Klasyków Filozofii.

Bentham J., Fragment on Government, [w:] tegoż, The Works of Jeremy Bentham, t. 1 [na podstawie zbioru pod red. J. Browninga, Edinburgh 1843], [online] http://oll.libertyfund.org/ title/2009 (29 XI 2012).

Bidwell G., Ostatni rycerz króla Artura, przeł. A. Bidwell, Katowice 2005, „Książica” Kieszonkowa. Bogdanor V., The New British Constitution, Oxford-Portland 2009.

Burke E., Rozważania o rewolucji we Francji. I o debatach pewnych towarzystw londyniskich zwiqzanych z tym wydarzeniem, wyrażone $w$ liście, który miat zostać wystany do pewnego gentlemana w Paryżu, przeł. D. Lachowska, wstęp P. Kłoczowski, Kraków-Warszawa 1994, Demokracja. Filozofia i praktyka.

Cosgrove R.A., The Rule of Law. Albert Venn Dicey, Victorian Jurist, London 1980.

Dicey A.V., An Introduction to the Study of the Law of the Constitution, wstęp i dodatek E.C.S. Wade, London 1945.

Dicey A.V., Lectures on the Relation between Law and Public Opinion during the 19th Century, [London 1919], [online] http://oll.libertyfund.org/title/1683.

Dicey A.V., Lectures on the Relation between Law and Public Opinion in England, Indianapolis 2008 [na podstawie wydania $\mathrm{z}$ roku 1917].

Dicey A.V., Letters to a Friend on Votes for Women, London 1909, [online] http://www.keele. ac.uk/history/currentundergraduates/tltp/SUFFRAGE/DOCUMENT/DICEYLEA. HTM\#Ret3.

Dicey A.V., Wstęp do nauki o prawie konstytucyjnem, przeł. W.H., Warszawa 1908.

Dworkin R., Bioracprawapoważnie, przeł. T.Kowalski, Warszawa 1998, Biblioteka Wspótczesnych Filozofów.

Fouillée A.J.É., L'idée moderne du droit en Allmagne, en Angleterre et en France, Paris 1878, za: B. Jasinowski, Wschodnie chrześcijaństwo a Rosja, wstęp M. Kornat, Kraków 2002, Biblioteka Klasyki Polskiej Myśli Politycznej, t. 9.

Habeas Corpus Act z 1679 roku, przeł. B. Lesiński, J. Walachowicz, [w:] Powszechna historia państwa i prawa. Wybór tekstów źródtowych, red. M.J. Ptak, M. Kinstler, Wrocław 1996.

Jaworski W.L., Nauka prawa administracyjnego. Zagadnienia ogólne, Warszawa 1924.

Jenks E., The Story of Habeas Corpus, [w:] Select Essays in Anglo-American Legal History, t. 2, Boston 1908.

Kaźmierczyk S., Jak rozumieć państwo prawne, [w:] Teoria i filozofia prawa. Wybór tekstów, red. W. Gromski, Wrocław 1998, Podręczniki Wydziatu Prawa i Administracji Uniwersytetu Wroctawskiego.

Kelly J.M., Historia zachodniej teorii prawa, przeł. D. Pietrzyk-Reeves [et al.], Kraków 2006.

Leksykon politologii, red. A. Antoszewski, R. Herbut, Wrocław 2002.

Maitland F.W., The Constitutional History of England, Cambridge 1908.

Mill J.S., O rzadzie reprezentatywnym, [w:] tegoż, O rządzie reprezentatywnym. Poddaństwo kobiet, przeł. J. Hołówka, Warszawa 1995, Demokracja. Filozofia i praktyka.

Mohl R. von, Die Polizeiwissenschaft nach den Grundlagen des Rechtsstaates, t. 1, Tübingen 1832, za: A. Bosiacki, Wstęp, [w:] R. von Mohl, Encyklopedia umiejętności politycznych, t. 1, przeł. A. Białecki, A. Bosiacki, Warszawa 2003. 
Mohl R. von, Encyklopedia umiejętności politycznych, t. 1, przeł. A. Białecki, A. Bosiacki, Warszawa 2003.

Monteskiusz, O duchu praw, przeł. T. Boy-Żeleński, posł. S. Łojek, Kraków 2003, Wielkie Dzieta Filozoficzne.

Morawski L., Wstęp do prawoznawstwa, Toruń 2002.

Petrażycki L., O nauce, prawie i moralności. Pisma wybrane, wybór J. Licki, A. Kojder, oprac. A. Kojder, Warszawa 1985, Biblioteka Socjologiczna.

Platon, Kriton, [w:] tegoż, Obrona Sokratesa. Kriton. Uczta, przeł. W. Witwicki, Warszawa 2008, Biblioteka Filozofów, 1.

Qvortrup M., A.V. Dicey. The referendum as the people's veto, „History of Political Thought” 1999 , t. 20, nr 3.

Radbruch G., Państwo praworządne, [w:] tegoż, Filozofia prawa, przeł. E. Nowak, Warszawa 2009.

Scruton R., Stownik myśli politycznej, przeł. T. Bieroń, Poznań 2002.

Stownik politologii, red. B. Walicka, Warszawa 2008, [na podstawie: Concise Dictionary of Politics, Oxford 2003].

Szerer M., Sądownictwo angielskie, Warszawa 1959.

Szlachta B., hasło: „Prawo”, [w:] Stownik spoteczny, red. B. Szlachta, Kraków 2004.

Thoreau H.D., Civil Disobedience, [w:] tegoż, Walden and Civil Disobedience, New York 2004.

Tocqueville A., Dawne rzady i rewolucja, przeł. W.M. Kozłowski [opracowanie z zachowaniem obowiązujących w 1907 r. zasad pisowni i interpunkcji], Warszawa 2003, Arcydzieta Wielkich Myślicieli.

Tukidydes, Wojna peloponeska, przeł. K. Kumaniecki, Warszawa 1988.

Wade E.C.S., Appendix, [w:] A.V. Dicey, An Introduction to the Study of the Law of the Constitution, wstęp i dodatek E.C.S. Wade, London 1945.

Weber M., Gospodarka i Spoteczeństwo. Zarys socjologii rozumiejącej, przeł. i wstęp D. Lachowska, Warszawa 2002, Biblioteka Socjologiczna.

Weill R., Dicey was not Diceyan, „The Cambridge Law Journal” 2003, t. 62, nr 2, [online] http:// dx.doi.org/10.1017/S000819730300638X.

Zamkowski W., Koncepcje i modele panstwa prawnego, [w:] Teoria i filozofia prawa. Wybór tekstów, red. W. Gromski, Wrocław 1998, Podręczniki Wydziatu Prawa i Administracji Uniwersytetu Wroctawskiego.

Zimmermann J., Prawo administracyjne, Warszawa 2008, Seria Akademicka; Prawo administracyjne, red. J. Boć, Wrocław 2007.

Michał ZABDYR-JAMRÓZ - absolwent politologii UJ, asystent w Zakładzie Polityki Zdrowotnej i Zarządzania, Instytucie Zdrowia Publicznego CM UJ, doktorant Wydziału Studiów Międzynarodowych i Politycznych UJ. Przygotowuje pracę doktorską na temat instytucjonalnego wymiaru zastosowania metod demokracji deliberatywnej. Naukowo zajmuje się także historią instytucjonalnych gwarancji praw człowieka (habeas corpus) oraz socjobiologią. 